University of Nebraska - Lincoln

DigitalCommons@University of Nebraska - Lincoln

Daugherty Water for Food Global Institute:

Faculty Publications

Daugherty Water for Food Global Institute

$3-2000$

\title{
Dynamic fluvial systems and gravel progradation in the Himalayan foreland
}

Nicholas Brozovic

Douglas W. Burbank

Follow this and additional works at: https://digitalcommons.unl.edu/wffdocs

Part of the Environmental Health and Protection Commons, Environmental Monitoring Commons, Hydraulic Engineering Commons, Hydrology Commons, Natural Resource Economics Commons, Natural Resources and Conservation Commons, Natural Resources Management and Policy Commons, Sustainability Commons, and the Water Resource Management Commons

This Article is brought to you for free and open access by the Daugherty Water for Food Global Institute at DigitalCommons@University of Nebraska - Lincoln. It has been accepted for inclusion in Daugherty Water for Food Global Institute: Faculty Publications by an authorized administrator of DigitalCommons@University of Nebraska Lincoln. 


\section{UC Santa Barbara \\ UC Santa Barbara Previously Published Works}

\section{Title}

Dynamic fluvial systems and gravel progradation in the Himalayan foreland

Permalink

https://escholarship.org/uc/item/9dt2k4wm

Journal

GEOLOGICAL SOCIETY OF AMERICA BULLETIN, 112(3)

ISSN

0016-7606

Authors

Brozovic, N

Burbank, DW

Publication Date

2000-03-01

DOI

10.1130/0016-7606(2000)112<0394:DFSAGP>2.3.CO;2

Peer reviewed 


\title{
Dynamic fluvial systems and gravel progradation in the Himalayan foreland
}

\author{
$\left.\begin{array}{l}\text { Nicholas Brozovic** } \\ \text { Douglas W. Burbank }\end{array}\right\}$ Department of Earth Sciences, University of Southern California, Los Angeles, California 90089
}

\section{ABSTRACT}

Although the large-scale stratigraphy of many terrestrial foreland basins is punctuated by major episodes of gravel progradation, the relationships of such facies to hinterland tectonism and climate change are often unclear. Structural reentrants provide windows into older and more proximal parts of the foreland than are usually exposed, and thus provide key insights to earlier phases of foreland evolution. Our magnetostratigraphic studies show that, although the major lithofacies preserved within the Himachal Pradesh structural reentrant in northwestern India resemble Neogene facies in Pakistan, they have a much greater temporal and spatial variability. From 11.5 to $7 \mathrm{Ma}$, major facies boundaries in Himachal Pradesh vary by as much as 2-3 m.y. across distances of 20-30 km and are controlled by the interference between a major southeastward-flowing axial river and a major southwestward-flowing transverse river. A thick but highly confined middle to late Miocene conglomerate facies includes the oldest extensive Siwalik conglomerates yet dated (10 Ma) and implies the development of significant erosional topography along the Main Boundary thrust prior to 11 Ma. Our studies document extensive syntectonic gravel progradation with conglomerates extending tens of kilometers into the undeformed foreland during a period of increased subsidence rate and within 1-2 m.y. of major thrust initiation. Overall, gravel progradation is modulated by the interplay among subsidence, sediment supply, and the proportion of gravels in rivers entering the foreland.

*Present address: Department of Agricultural and Resource Economics, University of California, Berkeley, California 94720; e-mail: brozovic@are. berkeley.edu.

${ }^{\dagger}$ Present address: Department of Geosciences, Pennsylvania State University, University Park, Pennsylvania 16802 .
Keywords: fold-and-thrust belt, basin analysis, Siwaliks, Himalaya, magnetostratigraphy.

\section{INTRODUCTION}

The evolution of terrestrial foreland basins is marked by the reorganization of fluvial systems on spatial scales of kilometers to thousands of kilometers at temporal scales ranging from coseismic to millennia (e.g., Meghraoui et al., 1988; Burbank, 1992; Talling et al., 1995; Pivnik and Johnson, 1995). Depositional systems within the foreland respond to changes in at least five factors: (1) flexure of the loaded plate, (2) incipient deformation at the leading edge of the encroaching load, (3) climate change, (4) hinterland rock types exposed to erosion, and (5) biological factors, particularly anthropogenic influences in the past several thousand years. Thus, sedimentary rocks potentially preserve information on paleoclimate, sediment flux, crustal structure, and basin dynamics. However, both field studies and numerical modeling demonstrate that there is considerable uncertainty in giving genetic interpretations to the sedimentological variations seen in real and synthetic foreland basins (Burbank, 1992; DeCelles, 1994; DeCelles et al., 1993; Flemings and Jordan, 1989, 1990; Fraser and DeCelles, 1992; Graham et al., 1986; Paola et al., 1992; Sinclair and Allen, 1992; Sinclair et al., 1991; Waschbusch and Royden, 1992; Watts, 1992).

Because the development of foreland basins is strongly asymmetric (Turcotte and Schubert, 1982; Allen and Allen, 1990), there is often a dichotomy in the interpretation of lateral and vertical facies variations. In proximal settings, facies variability is generally interpreted in terms of incipient structural disruption of the foreland (Pivnik and Johnson, 1995; Burbank et al., 1996). Sedimentologically similar variability in the medial or distal foreland may be linked to large-scale hinterland tectonic reorganization or climate change (e.g., Johnson et al., 1985; Burbank, 1992). In order to link proximal and distal depositional systems, it is necessary to synthesize data from across the foreland. Correlation among widely separated outcrops requires good time control. Terrestrial de- posits are generally marked by a paucity of fossil material of known age, making biostratigraphy difficult. In such areas without fossils or radiometrically dateable volcanic rocks, magnetostratigraphy can sometimes provide excellent temporal control if sufficiently long, continuous stratigraphic sections can be studied (Burbank, 1996).

\section{GEOLOGIC FRAMEWORK OF THE HIMALAYAN FORELAND}

India-Asia collision was initiated as early as $65 \mathrm{Ma}$ in the westernmost part of the orogen (Beck et al., 1995). Ongoing convergence has led to flexural downwarping of the overridden Indian plate, forming the Himalayan molasse basin, the world's largest terrestrial foreland basin (Fig. 1; Burbank, 1996; Watts, 1992). Due to subduction, uplift, and erosion, there is a dearth of preserved and exposed Paleogene foreland (Bossart and Ottiger, 1989; Critelli and Garzanti, 1994; Najman et al., 1993). From early Miocene time onward, however, there is a well exposed, continuous record of detritus shed from the Himalaya. These sedimentary rocks, deposited in a variety of fluvial regimes in the medial to distal part of the foreland, are known as the Rawalpindi and Siwalik Groups (Shah, 1977). The Siwalik strata traditionally have a tripartite division into the progressively younger Lower, Middle, and Upper Siwalik Formations (Shah, 1977): these roughly correspond to lithofacies (and have generally been regarded as chronofacies) dominated by siltstone, sandstone, and conglomerate, respectively.

The Himalayan foreland results primarily from subsidence driven by thrust loading. Sediment carried into the foreland by hinterland rivers can either be stored within the foreland or can bypass it and be transported by the Ganges or Indus Rivers to the sea, where it is stored in the Bengal fan or Indus cone. Sustained rapid Neogene accumulation within these deep-sea fans suggests that the Himalayan foreland was persistently filled to overflowing by sediment. Thus, the rate of sediment delivery from the hinterland is interpreted to have consistently exceeded the rate of creation of space to store the sediments within the foreland.

GSA Bulletin; March 2000; v. 112; no. 3; p. 394-412; 13 figures; 2 tables. 
$80^{\circ} \mathrm{E}$

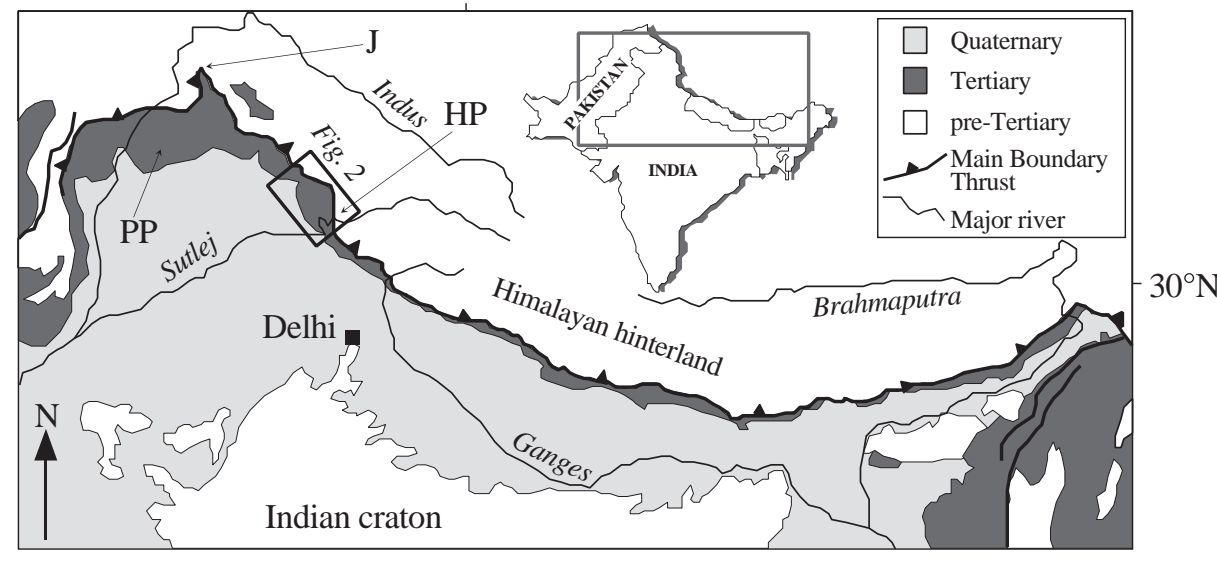

$200 \mathrm{~km}$

Figure 1. General location map, modified from Gansser (1964). HP-Himachal Pradesh reentrant, J-Jhelum reentrant, PP-Potwar Plateau. Major fault systems are not shown, except for the Main Boundary thrust. The eastern and western margins of the Main Boundary thrust are transpressional with a significant strike-slip component of motion. Major Tertiary sedimentary sequences also occur along the Upper Indus and Kathmandu valleys. The names of major rivers are shown italicized.

Over the past $20 \mathrm{yr}$, magnetostratigraphic studies have established a robust chronology for the Miocene-Pleistocene foreland in northwest India and Pakistan (Appel et al., 1991; Burbank and Beck, 1991; Burbank et al., 1986, 1988; G. D. Johnson et al., 1979, 1983; N. M. Johnson et al., 1982, 1985; Khan et al., 1988; Meigs et al., 1995; Mulder and Burbank, 1993; Raynolds and Johnson, 1985; Tauxe and Opdyke, 1982; and many others; for a complete review of Himalayan magnetostratigraphic studies, see Burbank, 1996). Nonetheless, there are still many unresolved questions concerning the evolution of the Himalayan foreland and the hinterland tectonic and climatic signals as recorded in its sedimentary rocks. The possible links between major climatic events such as Himalayan glaciation, the inferred strengthening of the Asian monsoon at 7-8 Ma, and the major alteration of atmospheric circulation patterns caused by uplift of the Tibetan Plateau are poorly understood, as are the impacts of these changes on denudation rates within the Himalaya and sediment flux to the foreland (Burbank, 1992; Burbank et al., 1993; Quade et al., 1989; Raymo and Ruddiman, 1992; Ruddiman and Kutzbach, 1989). The distribution of fluvial systems within the ancient foreland is poorly constrained, particularly the presence and downstream continuity of major axial drainages such as the paleo-Indus river (Burbank and Beck, 1991; Willis, 1993a, 1993b). The timing, partitioning, and magnitude of displacement along major Himalayan thrusts and the effect of irregularities in the evolving thrust load on basin subsidence and deposition has been defined in relatively few localities across this vast orogen (e.g., Macfarlane, 1993; Meigs et al., 1995; Srivastava and Mitra, 1994). The role of basement topography and preexisting faults in controlling depositional systems and structural style (i.e., thin- versus thick-skinned thrusting) has similarly been little studied (Karunakaran and Rao, 1979; Leathers, 1987; Lillie et al., 1987; Raiverman et al., 1983; Yeats and Lillie, 1991; Yeats et al., 1992).

\section{Structural Setting and Characteristics of the Himachal Pradesh Reentrant}

In northwest India, the Siwalik and Rawalpindi Groups are exposed within the Sub-Himalaya, an active thin-skinned fold-and-thrust belt between 30 and $80 \mathrm{~km}$ wide that accommodates some of the convergence between the Eurasian plate and the underthrusting Indian plate (Figs. 1 and 2; Lillie et al., 1987; Yeats and Lillie, 1991; Powers and Lillie, 1995). The northeastern boundary of the Sub-Himalaya is the Main Boundary thrust, an intracontinental megathrust, which places the Lesser Himalayan igneous and metamorphic sequences over the molasse basin. Although the trace of the Main Boundary thrust generally follows the sweeping arc of the Himalaya, it is perturbed by several salients and reentrants. The largest of these, the Jhelum and Himachal Pradesh reentrants, have dimensions of $\sim 100 \mathrm{~km}$ by $50 \mathrm{~km}$ (Figs. 1 and 2). They preserve older, more proximal sedimentary rocks than those seen elsewhere in the foreland: Eocene deposits within the Jhelum reentrant, and early Miocene Dharamsala and Eocene Subathu Formations within the Himachal Pradesh re- entrant. Several previous studies have considered sedimentation within reentrants of the Main Boundary thrust: the Jhelum reentrant (Raynolds, 1980; Raynolds and Johnson, 1985; Visser and Johnson, 1978), the Himachal Pradesh reentrant (Johnson and Vondra, 1972; Johnson et al., 1983; Meigs et al., 1995), and the Ravi reentrant (Tandon and Rangaraj, 1979). Within the Jhelum reentrant, excellent magnetostratigraphic time control, a high density of measured sections, and detailed sedimentology have allowed several studies to consider the impact of both the Main Boundary thrust and more local structures on foreland depositional systems (Burbank et al., 1988; Raynolds, 1980; Raynolds and Johnson, 1985). These studies document gravel progradation and focusing of fluvial systems by increased subsidence along the axis of the reentrant, and the competition between coeval axial and transverse drainages.

We present new sedimentologic and chronostratigraphic data from Miocene foreland basin strata exposed within the Himachal Pradesh structural reentrant of the Main Boundary thrust in northwest India (Fig. 2). These represent more proximal Miocene deposits than have been studied elsewhere within the Himalayan foreland, and include the oldest extensive Siwalik conglomerates yet dated $(10 \mathrm{Ma})$, suggesting that the Main Boundary thrust developed significant erosional topography prior to $10 \mathrm{Ma}$. Although there is no evidence for localized synsedimentary structural disruption, the study area shows extreme spatial and temporal variability in lithofacies, which may be linked to the longer term development of the reentrant. Moreover, this variability contrasts with the general uniformity of the more distal Miocene foreland preserved in Pakistan, and allows the possible impacts on foreland fluvial systems of the development of the Main Boundary thrust and the Himachal Pradesh reentrant to be evaluated. Our studies highlight the uniformity and contemporaneous character of some of the major basinal lithofacies as well as the diachrony of others over distances of kilometers to hundreds of kilometers.

\section{DATA SETS}

\section{Stratigraphy and Sedimentology}

Two new sections are described in this study, at Kangra and the Nalad Khad (Fig. 2). Together with the previously measured sections at Haritalyangar and Jawalamukhi (Johnson et al., 1983; Meigs et al., 1995), these are among the longest continuously exposed sections without major faulting that can be measured within the Siwalik sequence of the reentrant. The new sections at Kangra and the Nalad Khad were measured using a Jacob's staff and Abney level. Lithostratigraphy, paleocurrent directions, conglomerate-clast counts and facies 
variations were studied at all four sections within the reentrant. Measured paleocurrent indicators included trough and planar cross-stratification, furrows, scours, channel margins, parting current lineations, and conglomerate clast imbrications. Where necessary, paleocurrent measurements were corrected for the dip of strata and for postdepositional tectonic rotations as indicated by mean paleomagnetic vectors. Conglomerate-clast rock types were counted over a $1 \mathrm{~m}^{2}$ area, more than 100 clasts per locality. Major lithofacies boundaries were traced along the front of the Jawalamukhi thrust sheet using exposures along rivers and road cuts wherever possible, and binoculars and local topography in areas with poor access.

\section{Kangra Section}

The Kangra section is located at lat $32^{\circ} 2^{\prime} \mathrm{N}$, long $76^{\circ} 15^{\prime} \mathrm{E}$, in the hanging wall of the Jawalamukhi thrust sheet (Figs. 2 and 3). The 2300-m- thick section is characterized by an overall coarsening upward with distinct sedimentological boundaries that allow three major lithofacies to be defined, corresponding to the traditional Lower, Middle, and Upper Siwalik lithofacies (Figs. 4, A and B, and 5). The major rock types present in the lower $500 \mathrm{~m}$ of the section are interbedded siltstones, mudstones, and thin finegrained sandstones. Well developed red-brown soil horizons with rootlets are common, as are green finely laminated silts. Sandstone thickness is generally $5 \mathrm{~m}$ or less, though there are rare multistoried sandstones with an amalgamated thickness of 30-40 m (Fig. 4B). Paleocurrent indicators (mostly planar cross bedding) show flow to the southeast (Fig. 5). This facies is similar in appearance to the Lower Siwalik Chinji Formation in the Potwar Plateau (Fig. 1; Tauxe and Opdyke, 1982; N. M. Johnson et al., 1982, 1985).

The interval from $500 \mathrm{~m}$ to $2250 \mathrm{~m}$ is dominated by thicker sandstones separated by siltstone and clay intervals (Fig. 4, A and B). The sandstones are often multistoried with a thickness of as much as $45 \mathrm{~m}$ (though most are between 10 and $20 \mathrm{~m}$ ), and show a "salt-and-pepper" compositional texture. This texture is characteristic of the Middle Siwalik Nagri Formation in Pakistan and the Nahan Sandstone in India and suggests that this predominantly sandy facies at Kangra is either part of, or corresponds to, the Nahan Sandstone (Fig. 5; N. M. Johnson et al., 1982, 1985). Planar and trough cross-stratification are common, and woody material is uncommonly preserved (Fig. 4B). With height, there is a concurrent increase in average grain size, sandstone thickness and proportion, and the frequency of conglomerate lags. The siltstone intervals are often laminated and have numerous thin $(5-50 \mathrm{~cm})$ laterally discontinuous fine sandstone beds; occasional channel geometries are preserved. Red-brown soil horizons with rootlets, bioturbation, and common carbonate concretions are well developed throughout

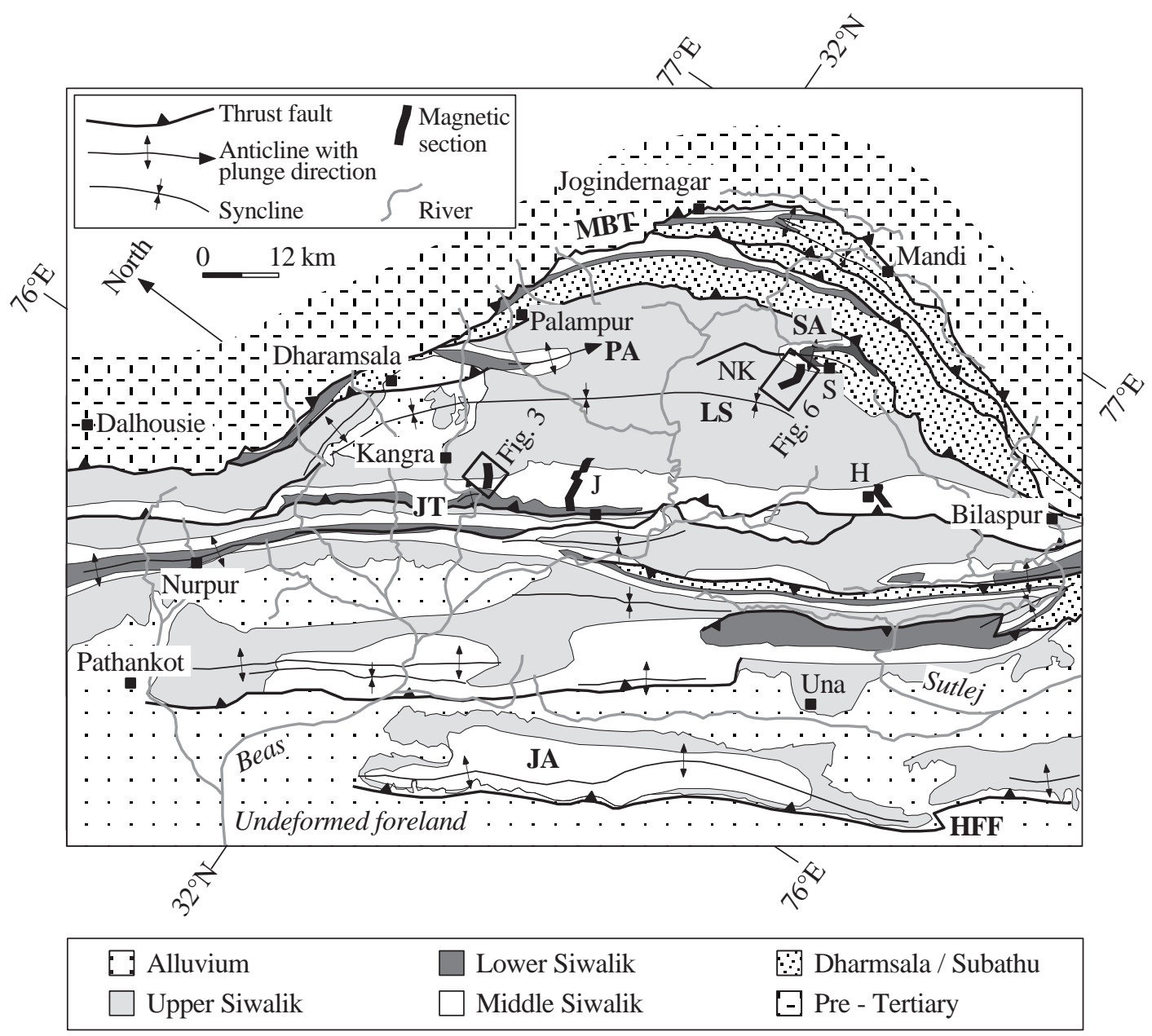

Figure 2. General location map of the Himachal Pradesh reentrant, modified from Raiverman et al. (1990). J-Jawalamukhi, S-Sarkaghat, NK—Nalad Khad, H-Haritalyangar. MBT_Main Boundary thrust, HFF—Himalayan Frontal fault, JT—Jawalamukhi thrust, SA—Sarkaghat anticline, PA-Paror anticline, JA-Janauri anticline, LS-Lambagraon syncline. The shading represents chronofacies and not lithofacies, and is based on detrital mineral assemblages and magnetostratigraphic time control (Johnson et al., 1983; Raiverman et al., 1990; Meigs et al., 1995; this study). The magnetic sections are named after adjacent towns or rivers. 
the facies, except in the last $150 \mathrm{~m}$, where green, gray, and lilac clays and laminated silts predominate. Paleocurrent directions within this facies are generally to the south, with a progressive shift to the southwest higher in the section (Fig. 5).

The change into laterally extensive and continuous clast-supported conglomerate at $2250 \mathrm{~m}$ is very abrupt. The conglomerates are massive with no fine-grained intervals, although there are common clay rip-ups up to several meters in size near the base of the unit (Fig. 4, A and B). The conglomerate clasts are well rounded and fairly well sorted; quartzite accounts for $45 \%$ of the clasts. Paleocurrent directions from imbricated clasts indicate flow to the southwest (Fig. 5). This conglomeratic facies is analogous to the Upper Siwalik Soan Formation in Pakistan and is known as the "Boulder Conglomerate" in northwest India (N. M. Johnson et al., 1982).

\section{Nalad Khad Section}

The Nalad Khad section is located at lat $31^{\circ} 46^{\prime} \mathrm{N}$, long $76^{\circ} 43^{\prime} \mathrm{E}$, on the western limb of the Sarkaghat anticline, and in the Jawalamukhi thrust sheet (Figs. 2 and 6). There is no exposure between the base of the $2200 \mathrm{~m}$ section and a major fault that cuts across the Nalad Khad about $500 \mathrm{~m}$ downstream from the base. Four major lithofacies occur within the section (Fig. 7, A and $\mathrm{B}$ ). The dominant lithology in the lower $1000 \mathrm{~m}$ of the section is coarse-grained sandstone. These sandstones are multistoried and commonly show "salt-and-pepper" texture, meter-scale planar cross-beds, matrix- and clast-supported conglomerate intervals, small channels (10-20 m across), and commonly preserved logs. In the lowest $300 \mathrm{~m}$ of the section, sandstone thickness varies from $<5 \mathrm{~m}$ to $40 \mathrm{~m}$, with interbeds of green laminated siltstone, gray clay, and occasional redbrown silty soil horizons (Figs. 5 and 7, A and B). From $300 \mathrm{~m}$ to $900 \mathrm{~m}$, very few strata are finer grained than medium sand, with average sandstone thicknesses increasing to $\sim 40 \mathrm{~m}$, though 100-m-thick sandstones are present. The amount of conglomerate also increases upsection, with pebble lags and discontinuous bands in the lower portion, as well as gravel-filled channels and 15-20-m-thick conglomerate beds in the upper portion. In the uppermost $100 \mathrm{~m}$ of the facies, there is a decrease in bed thickness and grain size, and there are more common red-brown siltstone interbeds. Paleocurrents in this facies are to the south-southwest in the lower portion, swinging westward with height (Fig. 5). The sedimentological similarity between this lithofacies, the Nagri Formation in Pakistan, and the Nahan Sandstone in northwest India suggests that it is part of the Nahan Sandstone lithofacies (Fig. 5; N. M. Johnson et al., 1982, 1985).

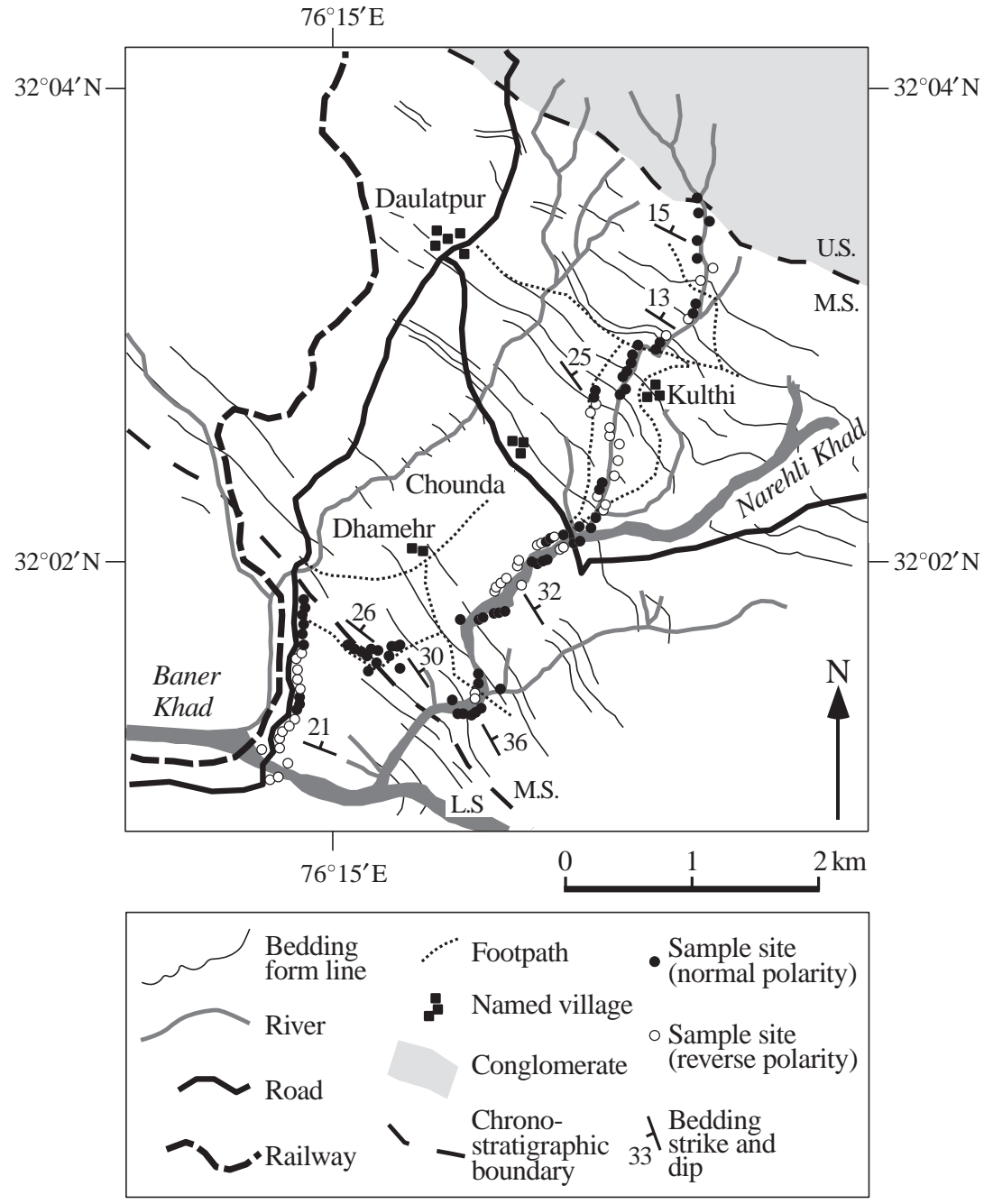

Figure 3. Location map of samples and measured section, Kangra. The area is covered by sheets $52 \mathrm{D} / 4$ and $52 \mathrm{D} / 8$ of the 1:63360 topographic series published by the Survey of India, 1926. L.S._Lower Siwalik, M.S.—Middle Siwalik, U.S.-Upper Siwalik. Bedding form lines and chronostratigraphic boundaries are based on unpublished Oil and Natural Gas Corporation reports (Dehrah Dun, India), and field mapping.

From 1100 to $1700 \mathrm{~m}$, the section is composed of thick, clast-supported, cobble-sized conglomerates with thin interbeds of orange-yellow sandstone and red-brown to orange siltstone (Fig. 7, A and B). Conglomerate thickness increases rapidly at the base of the facies from about $10 \mathrm{~m}$ to $>100 \mathrm{~m}$, and then decreases to $30-40 \mathrm{~m}$ in the upper portion of the facies (Fig. 5). White and pink quartzites are the dominant clasts, although sandstone clasts are also numerous (Fig. 5). Paleocurrents, based on clast imbrications, are to the westsouthwest (Fig. 5). This facies is similar in appearance to the ubiquitous Upper Siwalik "Boulder Conglomerate" and to the "Middle Siwalik conglomerate" described at Jawalamukhi by Meigs et al. (1995). The magnetostratigraphic correlation presented in the following suggests that it is within the "traditional" Middle Siwalik sequence and hence is part of the "Middle Siwalik conglomerate" lithofacies. This lithofacies is recognized only at Jawalamukhi and Nalad Khad.

From 1700 to $2100 \mathrm{~m}$, there is a finer grained interval, with interbedded green and red-brown siltstones, sands, and conglomerates generally 5-10 $\mathrm{m}$ thick (Fig. 7, A and B). Paleocurrents indicate flow to the west (Fig. 5). We suggest that this facies is part of the Middle Siwalik sandstone sequence, though not necessarily related to the other Middle Siwalik sandstones within the reentrant. At $2100 \mathrm{~m}$, the lithology abruptly changes to massive conglomerates, with occasional sandy bands and no finer material (Fig. 7, A and B). Once again, clast imbrications suggest a westward flow and clast compositions are dominated by quartzites (Fig. 5). This facies is part of the Upper Siwalik "Boulder Conglomerate," which is 


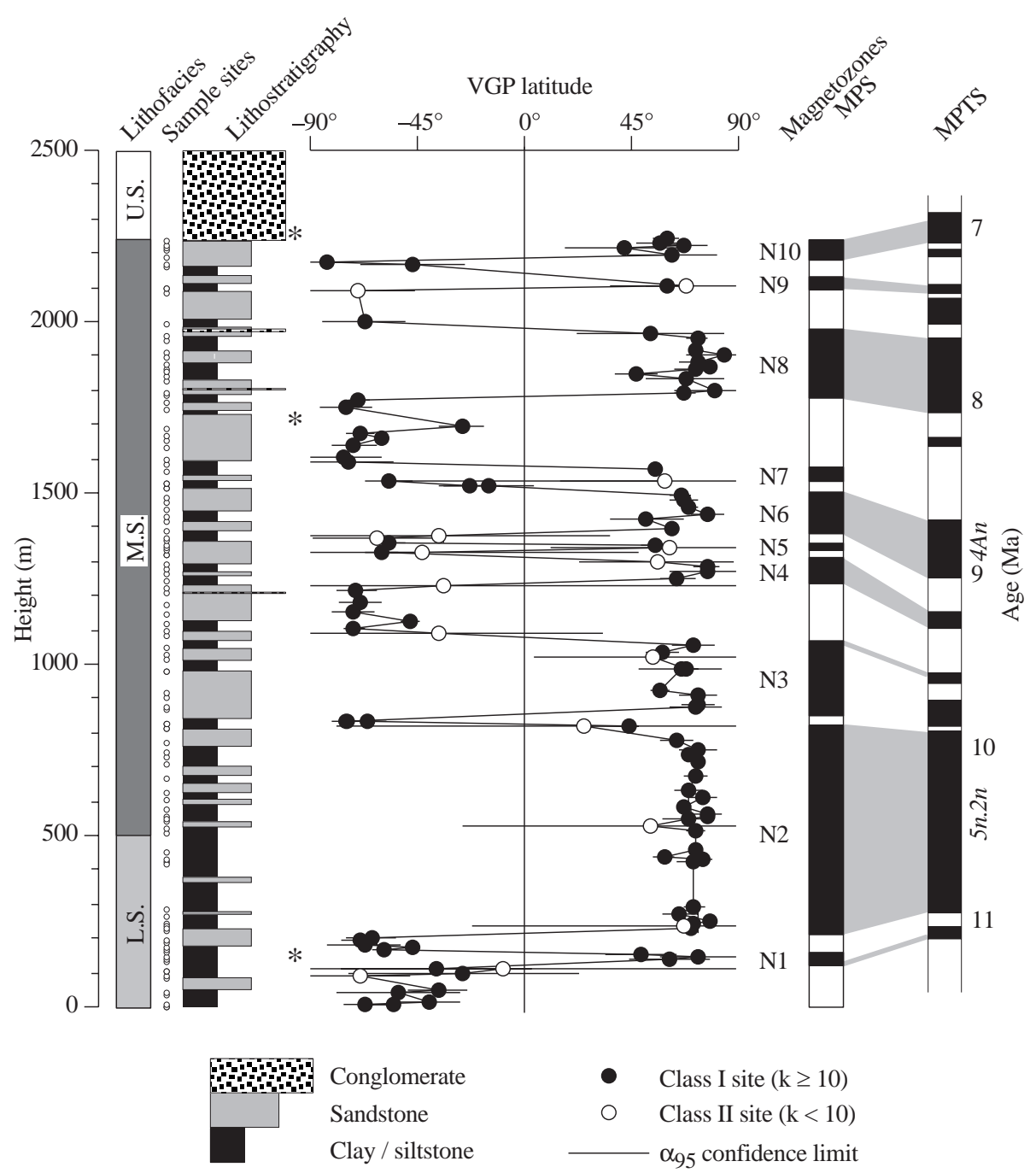

Figure 4. (A) Kangra stratigraphic section including the virtual geomagnetic pole (VGP latitude) determined for each site, the local magnetopolarity stratigraphy (MPS), and the preferred correlation to the global magnetic polarity time scale (MPTS) of Cande and Kent (1995). L.S.Lower Siwalik lithofacies, similar to Chinji lithofacies; M.S.-Middle Siwalik lithofacies, here interpreted as the Nahan Sandstone; U.S.-Upper Siwalik lithofacies ("Boulder Conglomerate"). An asterisk to the right of the lithostratigraphic column shows the location of the more detailed representative lithofacies logs shown in B. Small circles to the left of the lithostratigraphic column are the sites of paleomagnetic samples. Closed circles on the VGP plot are class I data ( $k \geq 10$; Fisher, 1953). Open circles are class II data ( $k<10$; Fisher, 1953). The $\alpha_{95}$ confidence limits for each latitude determination are shown by straight bars through individual sites. Boundaries between each magnetozone are chosen at the stratigraphic midpoint between sites of opposing polarity. Note that the samples from $\sim 200 \mathrm{~m}$ to $\sim 800 \mathrm{~m}$ show a long normal polarity interval (magnetozone N2). Chrons 5n.2n and 4An are labeled in italics next to the MPTS. The Kangra MPS is interpreted to span 11.3 Ma to 6.9 Ma.

found over a large part of the Lambagraon syncline within the Himachal Pradesh reentrant (Fig. 2; Johnson and Vondra, 1972).

\section{Jawalamukhi Section}

The Jawalamukhi section was described by Meigs et al. (1995). It is located at lat $31^{\circ} 53^{\prime} \mathrm{N}$, long $76^{\circ} 19^{\prime} \mathrm{E}$, in the hanging wall of the Jawalamukhi thrust sheet (Fig. 2). The thickness of the measured section is $3400 \mathrm{~m}$ (Fig. 8). From the base of the section to a height of $470 \mathrm{~m}$, the section consists of interbedded sandstones and green and red-brown siltstones. Soil horizons are well developed and the siltstones are often bioturbated with rootlets preserved. The sandstones are gener- ally thin (2-5 m); they have a maximum thickness of about $10 \mathrm{~m}$, the thicker beds occasionally showing planar cross-stratification (Fig. 5). Paleocurrents indicate flow to the southeast (Fig. 5). This lithofacies is sedimentologically similar to the Lower Siwalik Chinji Formation in the Potwar Plateau region (Tauxe and Opdyke, 1982; N. M. Johnson et al., 1982, 1985).

From $470 \mathrm{~m}$ to $1620 \mathrm{~m}$, the section is dominated by much thicker multistoried sandstones with thicknesses averaging $20-30 \mathrm{~m}$ but reaching $100 \mathrm{~m}$ (Fig. 5). Pebble lags and thin conglomerate beds are common and composed of wellrounded quartzite and other metamorphic and igneous clasts. Trough cross-stratification and other paleocurrent indicators show directions to the south, with a shift to the southwest with height (Fig. 5). This lithofacies is part of the Middle Siwalik Nahan Sandstone, and corresponds to the Nagri Formation in the Potwar Plateau region (N. M. Johnson et al., 1982, 1985).

At $1620 \mathrm{~m}$, thick extensive clast-supported conglomerates appear. These have broad scours and coarse stratification with individual stories generally 3-10 m thick (Fig. 5). There are occasional sandstone interbeds and sandy bands within the conglomerate, and rare silty bands. Clasts within the conglomerate include quartzite, igneous, and metamorphic rocks, and limestone (Fig. 5). Clast imbrications and cross-stratification suggest flow to the southwest (Fig. 5). Extensive conglomerate facies such as these do not appear in any other Middle Siwalik sections except at Nalad Khad. This lithofacies has been labeled "Middle Siwalik conglomerate" by Meigs et al. (1995).

From $2100 \mathrm{~m}$ to $2400 \mathrm{~m}$, there is a finer interval consisting of interbedded conglomerates, sandstones, siltstones, and clays (Fig. 5). These often occur in fining-upward sequences $15-20 \mathrm{~m}$ thick. Paleocurrent indicators are to the southwest (Fig. 5). At $2400 \mathrm{~m}$, there is a return to the conglomerate-dominated facies, with very little sandstone and finer material; this lithofacies continues to the top of the measured section. Multistoried conglomerate units between 10 and $150 \mathrm{~m}$ thick are separated by thin orange sandstones, siltstones, and clays (Fig. 5). Conglomerate clast imbrications suggest continued flow to the southwest (Fig. 5). This conglomeratic facies is part of the Upper Siwalik "Boulder Conglomerate" described by Johnson and Vondra (1972).

\section{Haritalyangar Section}

The stratigraphy of the Haritalyangar area was described by Johnson and Vondra (1972). The 1600 -m-thick section is located at lat $31^{\circ} 32^{\prime} \mathrm{N}$, long $76^{\circ} 37^{\prime} \mathrm{E}$ (Fig. 2), and is the southeasternmost section in the hanging wall of the Jawalamukhi thrust sheet. Johnson and Vondra (1972) defined four 


\begin{tabular}{|l|l|l|}
\hline & \multicolumn{4}{|c|}{ "Boulder Conglomerate" ("Upper Siwalik") } \\
GENERAL CHARACTERISTICS
\end{tabular}

Nahan Sandstone ("Middle Siwalik")
- Red-brown siltstone, concretionary layer near base
- Friable green fine sandstone
- Poorly exposed interbedded silt and/or medium sandstone
- Gray-green sandstone with occasional "floating" pebbles

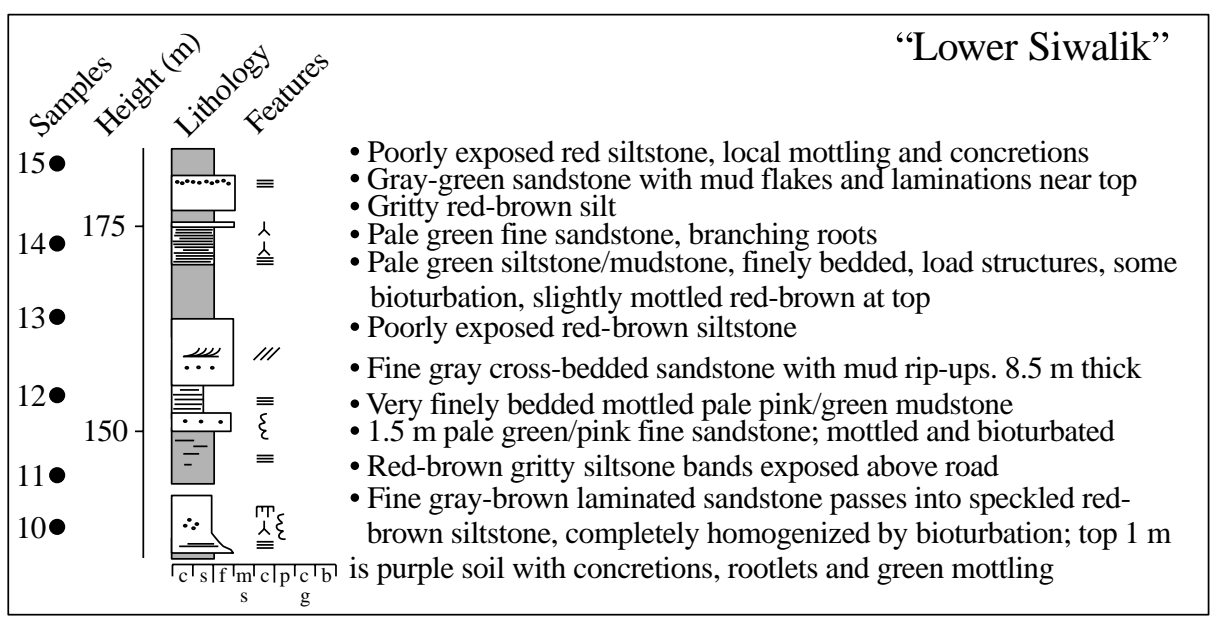

\begin{tabular}{|c|c|c|}
\hline \multirow{6}{*}{ 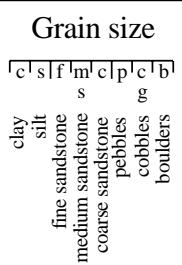 } & \multicolumn{2}{|c|}{ Sedimentary features } \\
\hline & III Planar cross bedding & Bedding trace \\
\hline & п Soil horizon & ... Carbonate concretions \\
\hline & $\xi$ Bioturbation & Gravel lag in sandstone 68 and number \\
\hline & $\wedge$ Rootlets & $\Longleftarrow$ Sandstone lense in conglomerate \\
\hline & $\equiv$ Lamination & $\curvearrowright$ Siltstone pocket in conglomerate \\
\hline
\end{tabular}

Figure 4. (B) Representative lithofacies for the Kangra section. Locations of each sedimentary log are shown as asterisks in $A$, and the interval in which the lithofacies is recognized is shown to the left of the stratigraphic column in A. Each log covers a stratigraphic interval of $50 \mathrm{~m}$ and shows stratigraphic height, lithology, grain-size variation, sedimentary features, and paleomagnetic sample locations. Conglomerate-clast counts and paleocurrent data are given where measured. Conglomerate-clast rock types: $\mathrm{Q}$ - quartzite, $\mathrm{L}-$ limestone, IM-igneous and metamorphic, $\mathrm{S}$-sandstone and siltstone, $\mathrm{O}$ - other. 

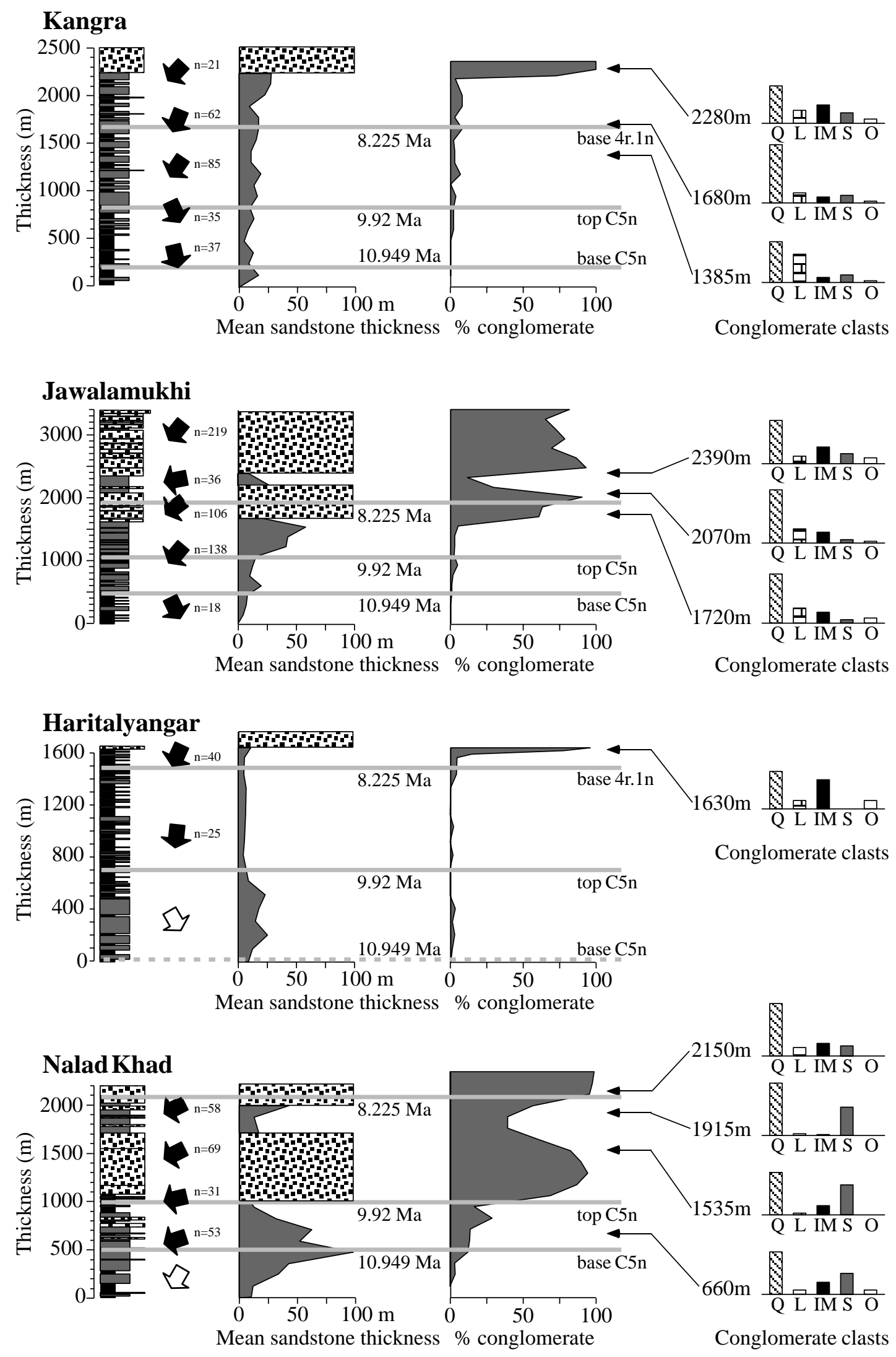
Figure 5. Sedimentological data for the Himachal Pradesh sections. The figure shows simplified lithostratigraphy (patterns follow Fig. 4A), paleocurrent directions, mean sandstone thicknesses, percentage of conglomerate, and conglomerate-clast counts for the four measured magnetic sections in Himachal Pradesh. Note that the vertical scale varies between sections, but that the vertical scale for all the data within each section is the same. The stratigraphic position and age of several chron boundaries are shown by thick gray lines for each section (base C4r.1n-8.225 Ma, top C5n-9.92 Ma, base C5n-10.949 Ma; Cande and Kent, 1995). The base of chron 5n is shown as a dashed gray line for the Haritalyangar section to indicate that this is stratigraphically the highest possible boundary, because the lowest magnetic sample in the section has a normal polarity. Mean paleocurrent directions are shown by the small arrows (up—north, down—south) and have been corrected for postdepositional vertical-axis rotations as shown by the section mean magnetic vectors (a positive angle represents clockwise postdepositional rotation and a counterclockwise correction of the same magnitude): $+14^{\circ}$ at Kangra, $+7^{\circ}$ at Haritalyangar, and negligible rotations at Nalad Khad and Jawalamukhi. Thick black arrows represent mean direction of paleocurrent indicators; the numbers to the right of the arrows indicate the number of paleocurrent measurements used. Thick white arrows indicate approximate flow direction only. Paleocurrent directions for the Jawalamukhi section are from A. J. Meigs (1992, unpublished data). The thickness of channel-fill sandstone beds was averaged over $125 \mathrm{~m}$ intervals. The percentage conglomerate was calculated as the amount of conglomeratic material over a $125 \mathrm{~m}$ interval. Conglomerate-clast rock types were counted over a $1 \mathrm{~m}^{2}$ area. The figure shows the relative proportions of each lithology counted, and the stratigraphic height and position of each count. Abbreviations as in Figure 4.

lithofacies for the Haritalyangar section (Fig. 8). The lowermost $500 \mathrm{~m}$ consists of interbedded sandstones and siltstones of the Nahan Sandstone. Multistoried sandstones with average thicknesses of 15-25 m dominate the section, and have a "saltand-pepper" texture, with common trough crossbedding, basal scours, and occasional pebble lags (Fig. 5). Orange to red-brown siltstones and clays are often mottled and soil horizons are generally well developed. Paleocurrents in the Nahan Sandstone indicate flow to the southeast (Fig. 5).
The Nahan Sandstone is transitional with the overlying "Lower Alternations," which are characterized by a decrease in average sandstone thickness to 10-15 $\mathrm{m}$, with an increase in the proportion of siltstone (Fig. 5). The "Lower Alternations" occur from 500 to $1170 \mathrm{~m}$ in the measured section, and are similar in appearance to the coeval Dhok Pathan lithofacies in the Potwar Plateau region of Pakistan (G. D. Johnson et al., 1982; N. M. Johnson et al., 1982). They are overlain by the "Upper Alternations," which are similar, though marked by a slight fining in sandstone thicknesses and a change in the composition of pebble lags toward an increased proportion of granitic and gneissic material (Johnson et al., 1983). The "Upper Alternations" have been correlated with the upper part of the Dhok Pathan lithofacies of the Potwar Plateau region (G. D. Johnson et al., 1982; N. M. Johnson et al., 1982). Paleocurrents in the "Lower" and "Upper Alternations" at Haritalyangar show a shift from the southeast toward the southwest (Fig. 5). The top of the "Upper Alternations" is

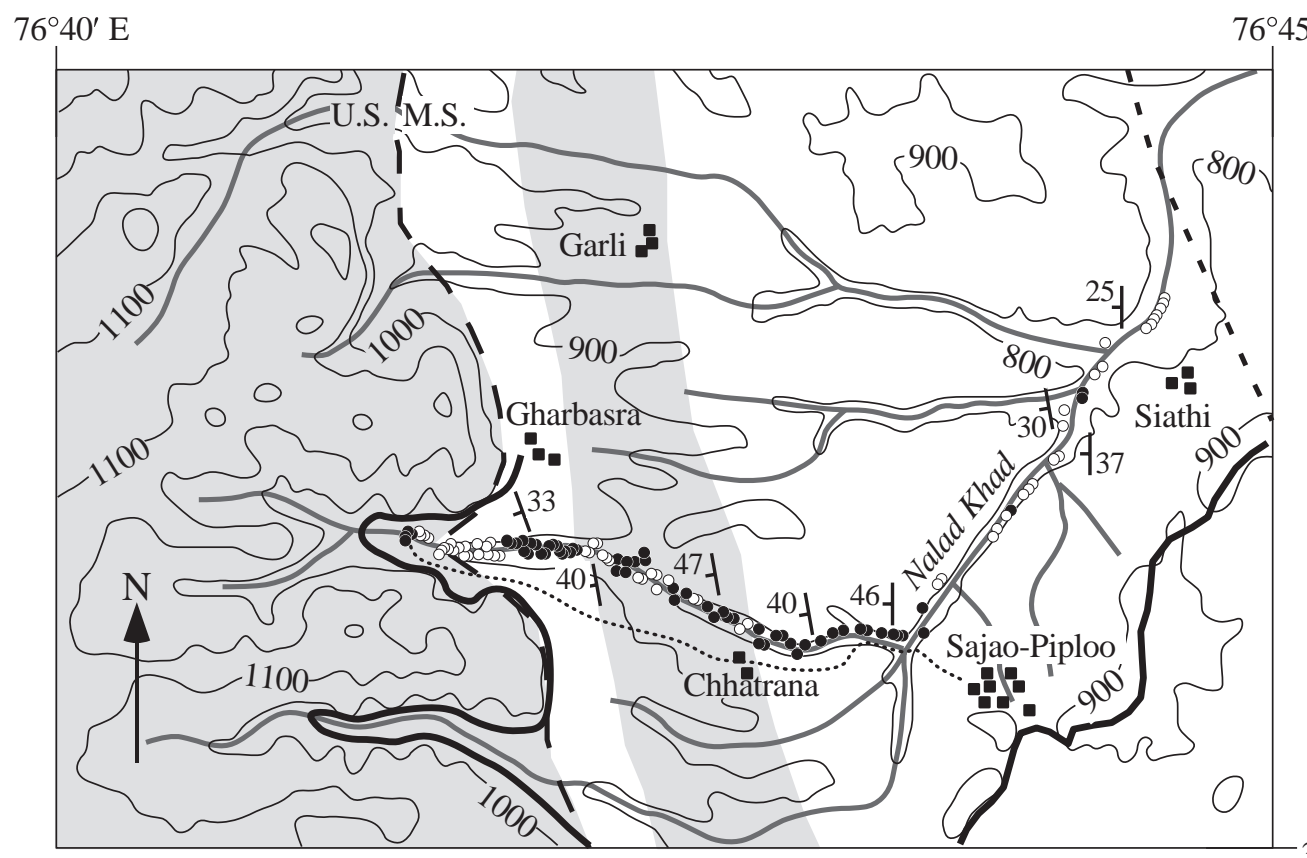

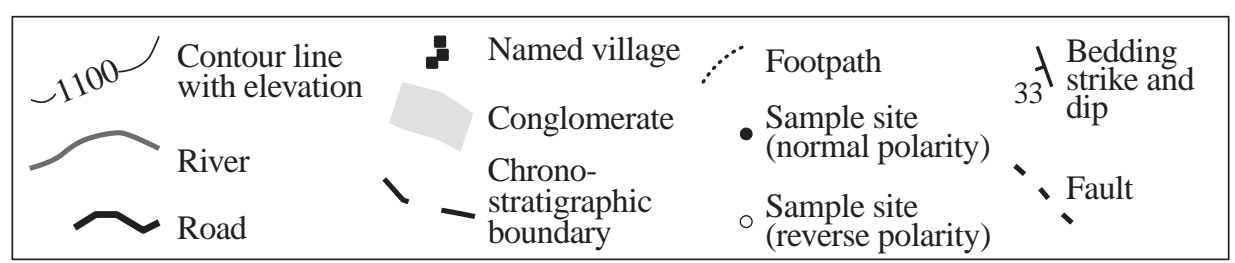

Figure 6. Location map of samples and measured section, Nalad Khad. The area is covered by sheet $53 \mathrm{~A} / 9$ of the 1:50 000 topographic series published by the Survey of India, 1973, from which the contours in the figure have been taken. L.S.-Lower Siwalik, M.S.-Middle Siwalik, U.S.-Upper Siwalik. Chronostratigraphic boundaries are based on field mapping. 
marked by a rapid increase in the amount of gravelly lag material and an abrupt transition into thick, extensive conglomerates of the Upper Siwalik "Boulder Conglomerate" lithofacies (Johnson and Vondra, 1972).

\section{PALEOMAGNETIC RESULTS AND CORRELATIONS}

New magnetic chronologies were established for the Kangra and Nalad Khad sections (Figs. 4A and 7A). Sampling for magnetic polarity stratigraphies (MPSs) focused on mudstones and silt- stones, as other rock types are usually either too weakly magnetized or too coarse grained to yield a primary depositional remanent magnetism. Oriented hand samples of suitable strata were collected, with four to six samples per site (stratigraphic level). The natural remanent magnetism (NRM) of the samples was measured on a cryogenic magnetometer at the University of Southern California. For each of the sections, representative pairs of samples were chosen from 20 stratigraphic levels, so that the full range of sample rock types and magnetic behavior was represented. Stepwise thermal demagnetization (measure-

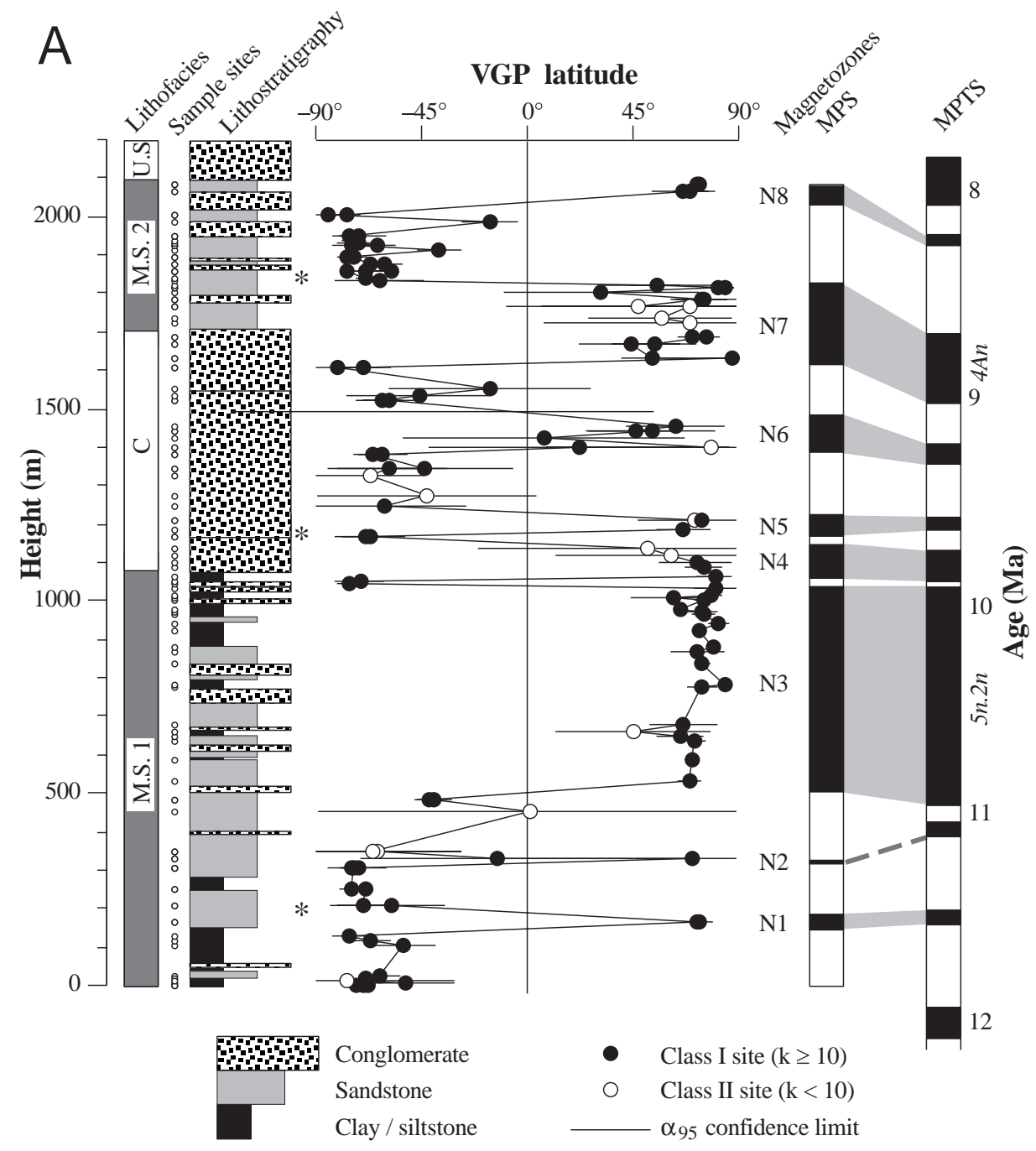

Figure 7. (A) Nalad Khad stratigraphic section including the virtual geomagnetic pole (VGP latitude) determined for each site, the local magnetopolarity stratigraphy (MPS), and the preferred correlation to the global magnetic polarity time scale (MPTS) of Cande and Kent (1995). L.S.—Lower Siwalik lithofacies, similar to Chinji lithofacies; M.S. 1-Middle Siwalik lithofacies, here interpreted as the Nahan Sandstone; C-Middle Siwalik conglomerate lithofacies; M.S. 2sandstone of Middle Siwalik age but interpreted as unrelated to the Nahan Sandstone; U.S.-Upper Siwalik lithofacies ("Boulder Conglomerate"). An asterisk to the right of the stratigraphic column shows the location of the more detailed representative lithofacies logs shown in $B$. For other symbols, refer to Figure 4A. The Nalad Khad MPS is interpreted to span 11.8 Ma to 8.3 Ma. ments at 100, 200, 300, 400, 450, 500, 525, 550, $575,600,625$, and $650{ }^{\circ} \mathrm{C}$ ) was conducted on these subsets to determine suitable demagnetization levels for the entire sample population. Magnetic susceptibilities were measured after each heating step to determine whether new magnetic minerals were growing at elevated temperatures (this would invalidate the sample data for steps of that temperature and higher).

The results indicate that there is a viscous overprint that is easily removed by thermal demagnetization at temperatures of $100-200{ }^{\circ} \mathrm{C}$ (Fig. 9). Some of the samples lost all of their NRM by $600^{\circ} \mathrm{C}$, while others retained relatively high magnetic intensities, suggesting that both magnetite and hematite are magnetic carriers. Above $200{ }^{\circ} \mathrm{C}$, most samples revealed a clear normal or reverse polarity, although samples with weaker intensities showed conversion to new minerals, as evidenced by increased susceptibilities at temperatures above $300{ }^{\circ} \mathrm{C}$. The more strongly magnetized samples generally showed a decline in intensity with a steady magnetization direction throughout thermal demagnetization. On the basis of these results, the remainder of the samples were divided into initially "strong" and initially "weak" samples. A stepwise thermal demagnetization was chosen with temperature steps of 400,450 , and $500{ }^{\circ} \mathrm{C}$ for initially "strong" samples $\left(\mathrm{J}_{0}>0.025 \mathrm{~A} / \mathrm{m}\right)$. Initially "weak" samples $\left(\mathrm{J}_{0}<0.025 \mathrm{~A} / \mathrm{m}\right)$ were thermally demagnetized first at 200,250 , and $300{ }^{\circ} \mathrm{C}$ and then at the three higher temperature steps; magnetic susceptibility measurements were made at each higher temperature step to determine whether new mineral growth was taking place. If magnetic susceptibilities changed significantly, indicating mineral growth, data from that temperature step were discarded and no higher temperature steps were measured.

After thermal demagnetization, magnetic vectors were corrected for sample orientation and bedding, and the dispersion between the sample magnetic vectors at each site, at each measured temperature step, was calculated using Fisher statistics (Fisher, 1953). For each site, data from the temperature step yielding the highest Fisher k value were used in site classification and further calculations. Following the classification described in Burbank and Johnson (1983), sites that showed a good agreement between all of the samples (Fisher k values >10) were termed class I (Fig. 10). Sites with unambiguous polarities but with Fisher $\mathrm{k}<10$ or sites with fewer than three surviving samples were classified as class II and unambiguous polarity. Sites for which no Fisher $k$ value could be calculated because the sample vectors were too dispersed and ambiguous data were termed class III, and discarded from further analysis. The total number of sites in this study was 244, with 1100 samples. These yielded 209 class I sites (86\%), 34 class II sites, and 1 class III site. 
Reversal and fold tests were applied to the paleomagnetic data following the procedures described in McFadden (1990) and McFadden and McElhinny (1990). Normal and reverse polarity limbs, each composed of the mean of class I and II site means with the same tectonic correction (McFadden, 1990), were used in the statistical analyses. Unfolded data for both the Nalad Khad and Kangra sections pass the reversal test of McFadden and McElhinny (1990) at the 95\% confidence limit (Tables 1A and 2A). Using their classification scheme, the Nalad Khad section has a ' $C$ ' classification with a critical angle of $10.55^{\circ}$, and the Kangra section has a ' $\mathrm{B}$ ' classification with a critical angle of $8.45^{\circ}$.

Both measured stratigraphic sections are within one dip panel on a major fold structure. However, for the Nalad Khad section it was possible to collect samples from a correlated stratigraphic level on the other side of the fold axis of the Sarkaghat anticline. Thus, it was possible to perform the fold test on an isolated observation (McFadden, 1990). The in situ Nalad Khad data fail the fold test at the $95 \%$ confidence level, whereas the unfolded data pass the fold test at the same confidence level (Table 1B). For the Kangra section, all paleomagnetic sites were located on a single dip panel. The correlation test of McFadden (1990) was applied to these data (Table 2B). Results of this statistical test are indeterminate for normal polarity limbs, although the value of the test statistic, $\xi_{2}$, is less for unfolded than in situ data. However, results from the reverse polarity limbs suggest that the magnetization was acquired before folding occurred. Taken together, these results, as well as the presence of both normal and reverse sites grouped in magnetozones, suggest that the magnetic vectors measured represent depositional remanence rather than an overprint.

Virtual geomagnetic poles (VGPs) and 95\% confidence intervals $\left(\alpha_{95}\right)$ for the paleolatitude were calculated for site means of the class I and II data. The VGP latitude allows magnetozones and a magnetic polarity stratigraphy to be established for each section. The $\alpha_{95}$ value is a further measure of the uncertainty in site polarity. The magnetic polarity stratigraphies can then be correlated with the global magnetic polarity time scale (MPTS). This study uses the MPTS of Cande and Kent (1995), and recorrelates preexisting magnetic polarity stratigraphies where older time scales have been used.

Several rigorous discussions of the uncertainties involved in using magnetostratigraphic studies for absolute age determinations have been published (Johnson and McGee, 1983; Talling and Burbank, 1993; Burbank, 1996). Johnson and McGee (1983) recommended a sample density of 20-25 sites/m.y. within Neogene strata to have a high likelihood of including all of the recorded re- versals with a few sites in each. Even though large portions of the measured sections were dominated by conglomerates, an adequate sample density was maintained, with $\sim 25$ sites/m.y. at Kangra and 35 sites/m.y. at Nalad Khad (Figs. 4A and 7A). Resampling of single site reversals was undertaken wherever possible to reinforce polarity determinations and minimize the risk of sampling errors or lightning strikes affecting the magnetic polarity stratigraphy; the Kangra section

"Middle Siwalik sandstone 2" GENERAL CHARACTERISTICS

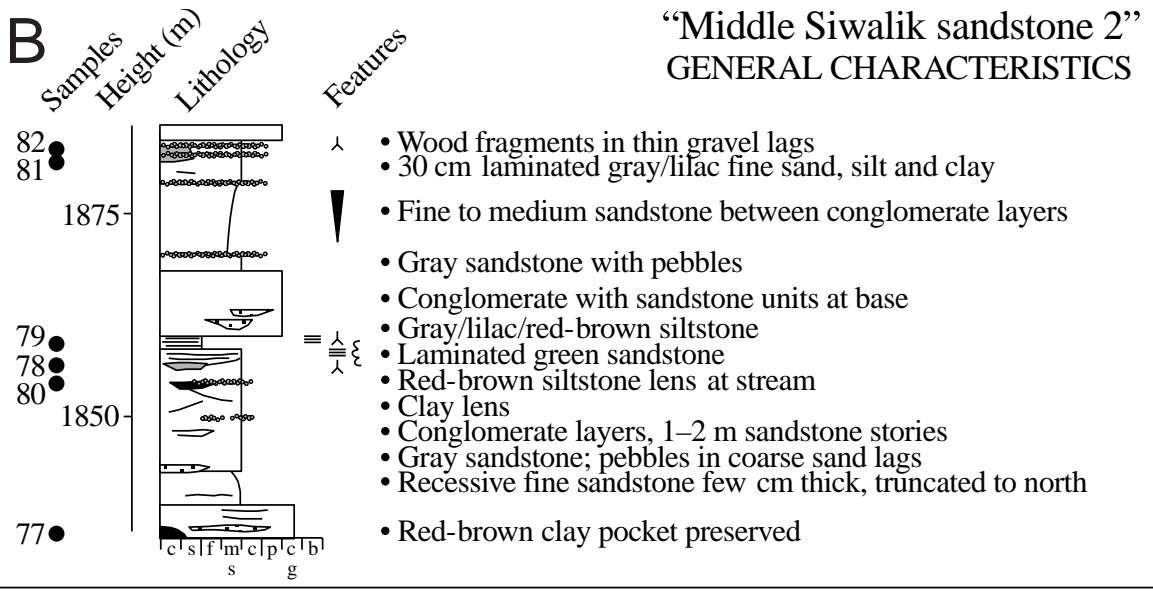

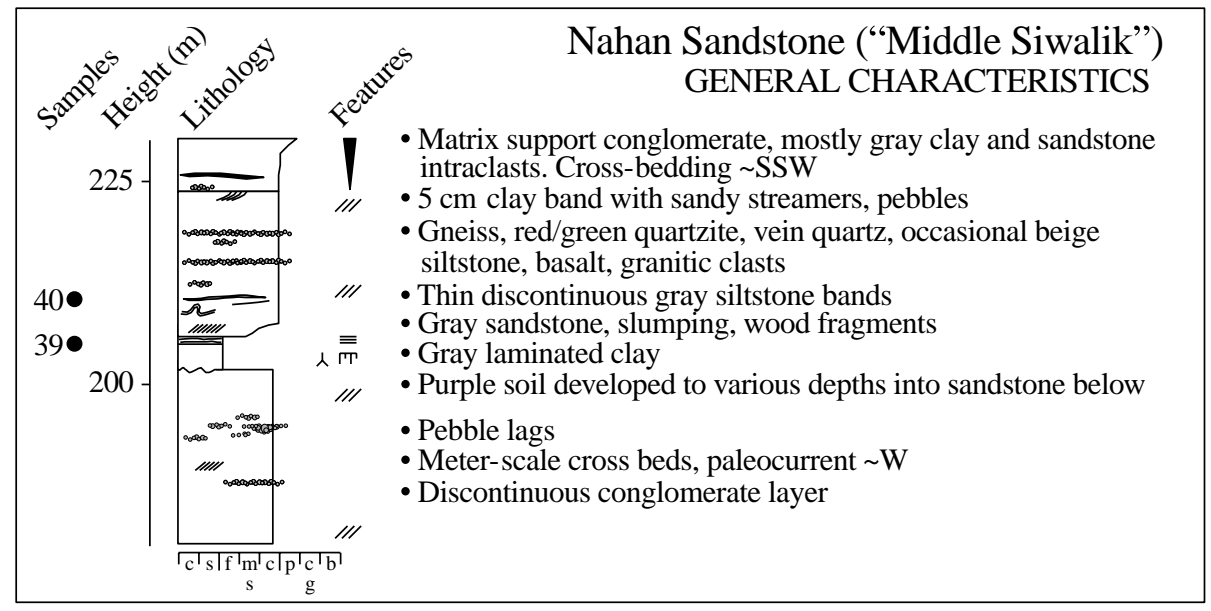

Figure 7. (B) Representative lithofacies for the Nalad Khad section. Locations of each sedimentary log are shown as asterisks in $\mathrm{A}$, and the interval in which the lithofacies is recognized is shown to the left of the stratigraphic column in A. See Figure 4B for further explanations. No log is shown for the Upper Siwalik "Boulder Conglomerate" lithofacies; it is similar in appearance to both the Middle Siwalik conglomerate lithofacies in this figure and to the "Boulder Conglomerate" lithofacies shown in Figure 4B. 


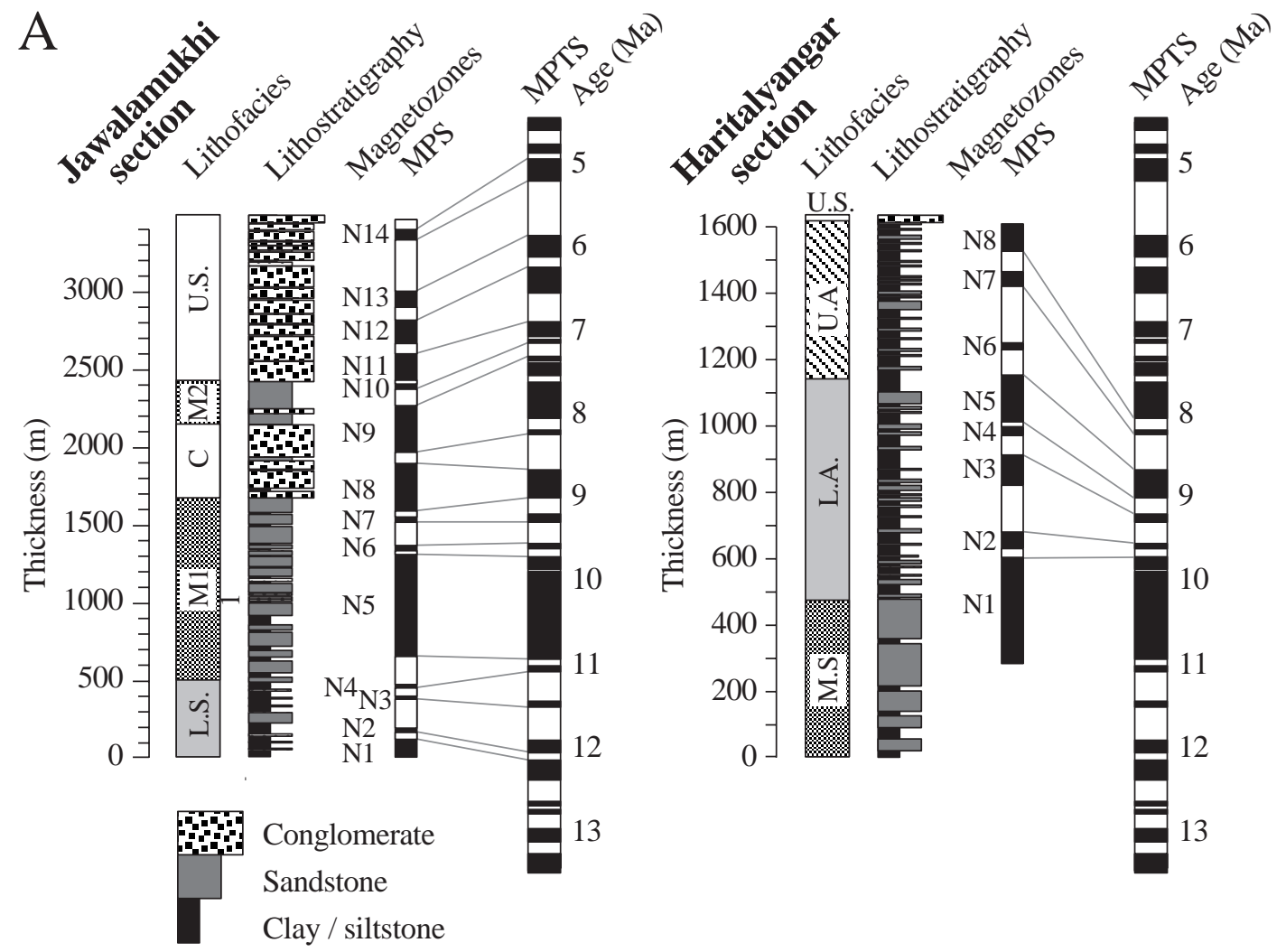

B

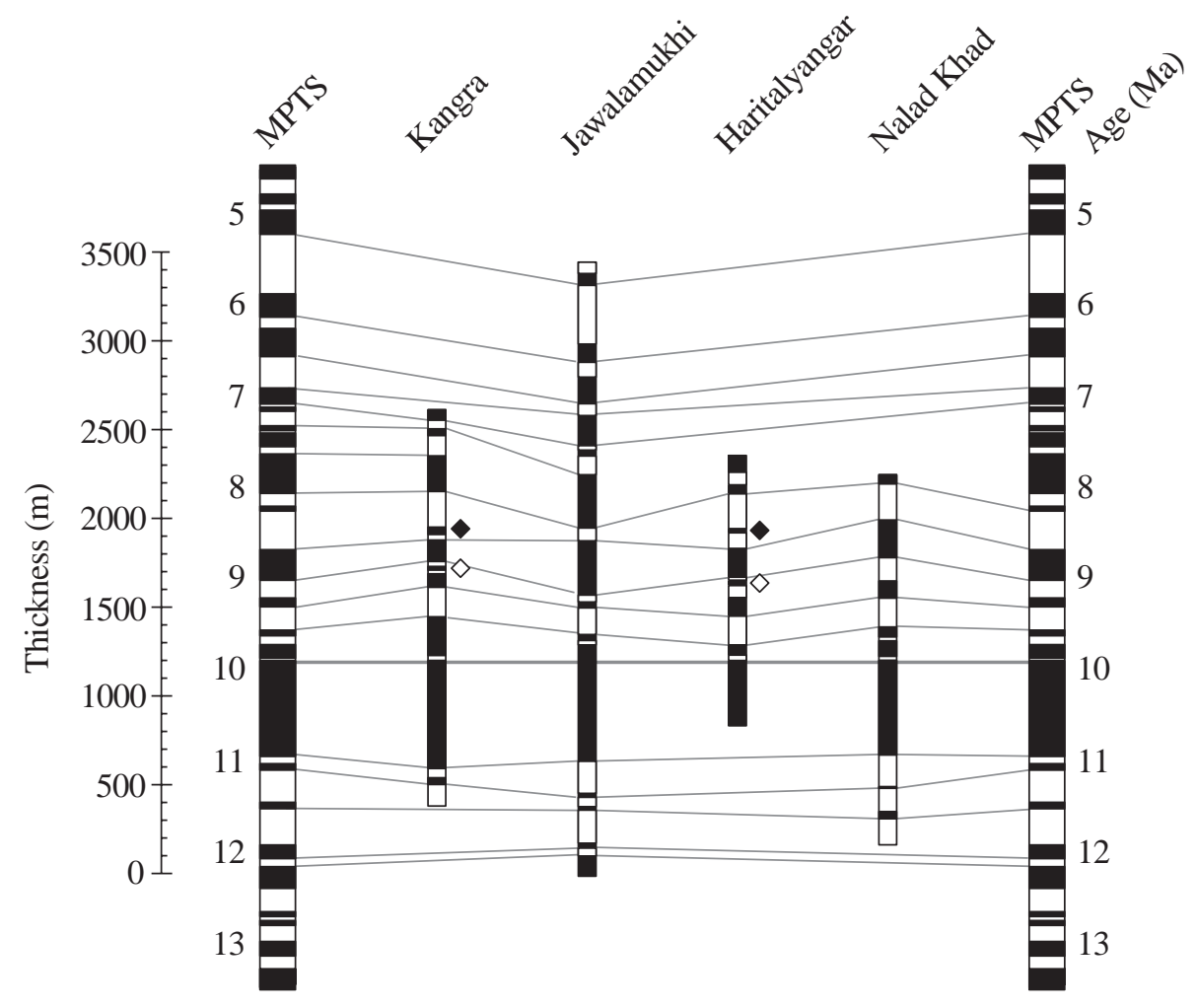


Figure 8. (A) Stratigraphic sections and local magnetic polarity stratigraphies (MPSs) for the Jawalamukhi and Haritalyangar sections, after Meigs et al. (1995) and Johnson et al. (1983), respectively. Both MPSs have been recorrelated to the global magnetic polarity time scale (MPTS) of Cande and Kent (1995). These recorrelations produce similar sediment accumulation rates in all four sections within the reentrant, as well as bring fauna at Haritalyangar (Johnson et al., 1983) into concurrence with similar fauna in Pakistan (e.g., Tauxe, 1979). Note that the vertical scales are different for the Jawalamukhi and Haritalyangar sections, but that the global magnetic polarity time scale used in the correlations has the same vertical scale. For the Jawalamukhi section, lithofacies are: L.S.—Lower Siwalik, similar to Chinji lithofacies; M1—Middle Siwalik, here interpreted as the Nahan Sandstone; C-Middle Siwalik conglomerate; M2-sandstone of Middle Siwalik age but interpreted as unrelated to the Nahan Sandstone; U.S._-Upper Siwalik ("Boulder Conglomerate"). For the Haritalyangar section, lithofacies are: L.S.-Lower Siwalik, similar to Chinji lithofacies; M.S.—Middle Siwalik, here interpreted as the Nahan Sandstone; L.A._-Lower Alternations" of Johnson et al. (1983); U.A.—“Upper Alternations" of Johnson et al. (1983); U.S.—Upper Siwalik ("Boulder Conglomerate"). (B) Correlation of the Himachal Pradesh local magnetic polarity stratigraphies with the global magnetic polarity time scale (MPTS; Cande and Kent, 1995). The vertical scale is stratigraphic thickness, so that nonparallelism of time lines (shown in gray) represents varying sediment accumulation rates between sections. The thick horizontal time line is the top of chron 5n.2n (9.92 Ma), and is used as a datum for the magnetic sections. Note that the Kangra, Jawalamukhi, and Haritalyangar sections are along strike from each other, whereas the Nalad Khad section is located in a more proximal position in the foreland (Fig. 2). The magnetozones denoted by a black diamond in the Kangra and Haritalyangar MPSs (N7 and N6, respectively) have been correlated with a cryptochron immediately above the top of chron 4An (8.699 Ma) described in Cande and Kent (1992). The magnetozones denoted by a white diamond in the Kangra and Haritalyangar MPSs (N5 and N4, respectively) have been correlated with a very short cryptochron, which does not appear in the MPTS but has been described in several magnetic sections in Pakistan (Tauxe, 1979; Tauxe and Opdyke, 1982).

contains no single site reversals and the Nalad Khad section contains one. The data quality of both the Himachal Pradesh magnetic polarity stratigraphies is excellent, and gives us confidence in the correlations chosen and in the interpretations of stratigraphic and sedimentologic data we present based on this time control.

The key to correlation for many of the magnetic polarity stratigraphies established within the Siwalik foreland to the MPTS (Cande and Kent, 1995) is the presence of a long normal polarity interval in each section that coincides with the thick Nagri Formation sandstone in Pakistan and to the Nahan Sandstone in northwest India (G. D. Johnson et al., 1982; N. M. Johnson et al., 1982, 1985; Meigs et al., 1995). This interval has been correlated with chron $5 \mathrm{n} .2 \mathrm{n}$ (10.949-9.92 Ma; Cande and Kent, 1995) on the basis of faunal assemblages and fissiontrack ages from ash horizons (G. D. Johnson et al., 1982).

In the Kangra section, 500 paleomagnetic samples were collected at 113 sites, which on measurement yielded 97 class I sites (86\%), 16 class II sites, and no class III sites (Fig. 4A). This defines a local magnetic polarity stratigraphy with 17 reversals, 18 magnetozones, and no single site reversals (Fig. 4A). Magnetozone N2 is a long normal polarity magnetozone that includes the base of the Nahan lithofacies and has been correlated with chron 5n.2n (Fig. 4A). The remaining magnetozones have been correlated to the MPTS with the assumption that most chrons will have been detected due to the high sample density; hence the Kangra section spans 11.3 to $6.9 \mathrm{Ma}$. The slightly lower sample density near the top of the section leads to some uncertainty in the correlation, which could yield variations of $0.1-0.2 \mathrm{~m} . \mathrm{y}$. in the age of the top of the section. Magnetozone N7 of the Kangra magnetic polarity stratigraphy has been correlated with a cryptochron immediately above the top of chron 4An (8.699 Ma), which is described in the MPTS of Cande and Kent (1992); this cryptochron also occurs in the Haritalyangar magnetic polarity stratigraphy (see the recorrelation of Meigs et al., 1995). Magnetozone N5 of the Kangra magnetic polarity stratigraphy is a short normal polarity magnetozone ( 2 class I sites at a height of $1340 \mathrm{~m}$ ) that is not repre-
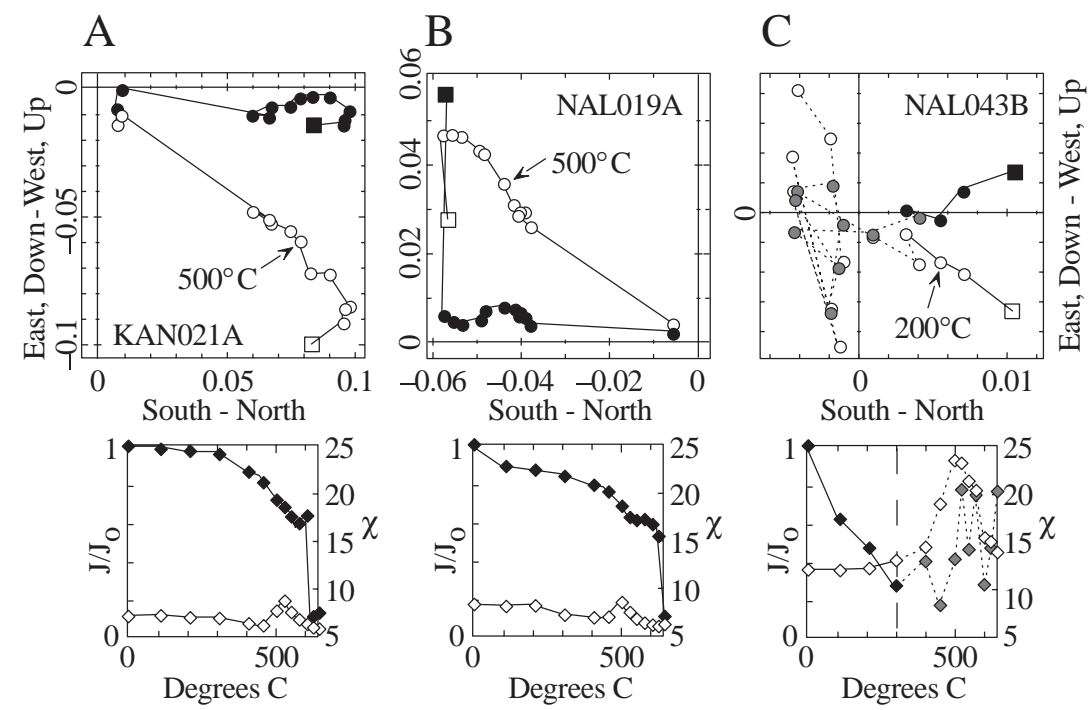

Figure 9. Zijderveld plots of vertical plane (open circles) and horizontal plane projections (filled circles) from representative thermally demagnetized samples, and plots of relative intensity (filled diamonds) and magnetic susceptibility (open diamonds) vs. temperature. The square data points on the Zijderveld plots represent initial measurements. The scale for the Zijderveld plots is $\mathbf{A} / \mathbf{m}$. Relative intensity is calculated as initial sample intensity/sample intensity for that temperature step. Both relative intensity and magnetic susceptibility are dimensionless. (A) The site mean direction indicates normal polarity for sample KAN021A (north declination, down inclination), with progressive removal of an overprint at temperatures from 100 to $300{ }^{\circ} \mathrm{C}$. (B) Sample NAL019A shows a reverse polarity (south declination, up inclination) and a low-temperature overprint, which is removed by $100{ }^{\circ} \mathrm{C}$. (C) Sample NAL043B is a weak sample that shows a normal polarity at temperatures up to $300{ }^{\circ} \mathrm{C}$, with random inclinations and declinations at higher temperatures. The increasing intensity and magnetic susceptibility above $300{ }^{\circ} \mathrm{C}$ suggest the growth of new minerals and obliteration of the original magnetic vector. Measurements from temperature steps higher than $300^{\circ} \mathrm{C}$ were discarded from the calculation of the polarity of this sample, and are shown joined with a dashed line and shaded gray. 
TABLE 1A. NALAD KHAD SECTION REVERSAL TEST

\begin{tabular}{|c|c|c|c|c|c|c|}
\hline Un & $i$ & Declination & Inclination & $V_{i}$ & $R_{i}$ & $k_{i}$ \\
\hline & & & & & 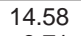 & \\
\hline (imvericu) & $L_{-}$ & 000.1 & & 10 & 9.71 & \\
\hline \multicolumn{7}{|c|}{$\begin{array}{l}\text { Notes: The number of limbs (sensu McFadden, 1990) for each polarity, } i \text {, is given by } N_{i} R_{i} \text { is the length of the } \\
\text { ector sum of unit vectors for each polarity, and } k_{i} \text { is the estimate of the distribution precision, } \kappa_{i} \text {, defined as } \\
k_{i}=\left(N_{i}-1\right) /\left(N_{i}-R_{i}\right) \text {. See McFadden and McElhinny (1990) for details. Hence, } k_{1} / k_{2}=1.09 \text { and } F_{0.05}(15,10)=2.85 \text {. } \\
\text { since } F_{0.05}(15,10)>1.09 \text {, a common } \kappa \text { can be assumed, and the reversal test with several observations per } \\
\text { olarity and a common precision can be performed (McFadden and McElhinny, 1990). Thus, } N=N_{1}+N_{2}=25 \text {, and } \\
\text { he relevant angles are } \gamma_{0}=9.80^{\circ} \text { and } \gamma_{c}=10.55^{\circ} \text {, where } \gamma_{0} \text { is the observed angle between the two mean } \\
\text { lirections and } \gamma_{c} \text { is the critical angle between the two mean directions at which the null hypothesis of a common } \\
\text { nean direction would be rejected with } 95 \% \text { confidence. Since } \gamma_{0}<\gamma_{c} \text { and } 10^{\circ} \leq \gamma_{c} \leq 20^{\circ} \text {, the data pass the } \\
\text { eversal test at the } 95 \% \text { confidence level, with a 'C' classification. }\end{array}$} \\
\hline
\end{tabular}

TABLE 1B. NALAD KHAD SECTION FOLD TEST

\begin{tabular}{lcccccc}
\hline \hline Limbs & $N$ & $\mu_{N^{*}}$ & $\boldsymbol{F T}^{\dagger}$ & $R_{N}$ & $\gamma_{0}$ & $\operatorname{Prob}\left(\gamma>\gamma_{0}\right)$ \\
\hline In situ & 14 & $019.8,20.8$ & $292.7,74.9$ & 13.61 & $51.38^{\circ}$ & 0.000236 \\
Unfolded & 14 & $358.7,33.7$ & $018.6,32.3$ & 13.62 & $16.64^{\circ}$ & 0.279 \\
\hline
\end{tabular}

Notes: The number of limbs (sensu McFadden, 1990) is given by $N, \mu_{N}$ is the mean vector of limbs with normal sites within one dip panel, and $\boldsymbol{F} \boldsymbol{T}$ is the unit vector for the isolated observation on the second limb. $R_{N}$ is the length of the vector sum of the $N$ unit vectors, and $\gamma_{0}$ is the observed angle between $\mu_{\boldsymbol{N}}$ and $\boldsymbol{F T}$. The final column is the probability of obtaining an angle greater than $\gamma_{0}$, and is a test of whether the isolated observation is discordant with the other observations (McFadden, 1990). Thus, the in situ data fail the fold test at the $95 \%$ confidence level, whereas the unfolded data pass the fold test at the $95 \%$ confidence level.

*The values given for $\mu_{N}$ are the declination and inclination, in degrees, respectively.

tThe values given for $\boldsymbol{F} \boldsymbol{T}$ are the declination and inclination, in degrees, respectively.

sented in any recent global magnetic polarity time scale. However, several other magnetostratigraphic studies in the Himalayan foreland have identified this short normal polarity interval at about 9.2 Ma (Tauxe, 1979; Tauxe and Opdyke, 1982). It seems likely that this short normal interval represents either a regional or global event of very short duration, which has been fortuitously preserved in some Siwalik sections due to relatively high sediment accumulation rates.

We collected 600 paleomagnetic samples at 129 sites in the Nalad Khad section, which on measurement yielded 110 class I sites (85\%), 18 class II sites, and 1 class III site (Fig. 7A). This defines a magnetic polarity stratigraphy with 15 reversals, 16 magnetozones, and one single site reversal. Magnetozone N3 is a long normal polarity interval that coincides with the Nahan Sandstone lithofacies and has been correlated with chron 5n.2n (10.949-9.92 Ma; Cande and Kent, 1995); on this basis the section spans 11.8 Ma to 8.3 Ma (Fig. 7A). An alternative correlation is possible for the Nalad Khad section, with the long normal magnetozone correlated to chron 4n.2n (7.65-8.072 Ma; Cande and Kent, 1995 ), and the section spanning $8.4 \mathrm{Ma}$ to 6.5 Ma. This alternative has been rejected because, in comparison to the other sections in the reentrant, it gives unrealistically high sediment accumulation rates (a threefold increase in rate over a distance of $30 \mathrm{~km}$, and rates $50 \%$ higher than recorded anywhere else in the foreland) and requires a retrogradation of hinterlandsourced facies at the same time that analogous facies were prograding everywhere else.
At Jawalamukhi, the study of Meigs et al. (1995) defined a magnetic polarity stratigraphy with 27 reversals, 28 magnetozones, and one single site reversal (Fig. 8); of the 134 sites, $70 \%$ yielded class I data. Magnetozone N5 is a long normal polarity interval that coincides with deposition of the Nahan Sandstone at Jawalamukhi and has been correlated with chron 5n (Burbank, 1996). Correlation with the MPTS (Cande and Kent, 1995) dates the section as spanning $12.3 \mathrm{Ma}$ to 4.7 Ma (Fig. 8; Meigs et al., 1995).

The upper $1200 \mathrm{~m}$ of the section at Haritalyangar were sampled for magnetostratigraphy by Johnson et al. (1983); samples in the lower $400 \mathrm{~m}$ of the section were collected by R. A. Beck (described in Meigs et al., 1995). A total of 91 paleomagnetic sites through the Haritalyangar section define a magnetic polarity stratigraphy with 14 reversals, 15 magnetozones, and 3 single site reversals (Johnson et al., 1983; Burbank, 1996; Fig. 8). Our preferred correlation with the MPTS dates the section as spanning 10.5 Ma to 7.6 Ma (Meigs et al., 1995; Burbank et al., 1996; Fig. 8). This represents a recorrelation of the original Haritalyangar magnetic polarity stratigraphy, and implies that the top of the measured section dates from about 7.6 Ma (Meigs et al., 1995; Burbank, 1996) rather than about $5 \mathrm{Ma}$, as originally suggested by Johnson et al. (1983). A recorrelation of the original data was undertaken for three reasons: (1) newer MPTSs have a more detailed reversal structure during late Miocene time, changing the most likely correlation (Cande and Kent, 1992, 1995); (2) recorrelation of the Haritalyangar section produces sediment accumulation rates that are similar to those along strike at Jawalamukhi and Kangra (Fig. 8); and (3) recorrelation brings the Haritalyangar fauna into con-
TABLE 2A. KANGRA SECTION REVERSAL TEST

\begin{tabular}{lcccccc}
\hline \hline Unfolded limbs & $i$ & Declination & Inclination & $N_{i}$ & $R_{i}$ & $k_{i}$ \\
\hline Normal polarity & 1 & $015.6^{\circ}$ & $29.6^{\circ}$ & 23 & 22.48 & 42.23 \\
Reverse polarity (inverted) & 2 & $021.1^{\circ}$ & $28.9^{\circ}$ & 18 & 17.20 & 21.13 \\
\hline
\end{tabular}

Notes: The number of limbs (sensu McFadden, 1990) for each polarity, $i$, is given by $N_{i} \cdot R_{i}$ is the length of the vector sum of unit vectors for each polarity, and $k_{i}$ is the estimate of the distribution precision, $\kappa_{i}$, defined as $k_{i}=\left(N_{i}-1\right) /\left(N_{i}-R_{i}\right)$. See McFadden and McElhinny (1990) for details.

Hence, $k_{1} / k_{2}=2.00$ and $F_{0.05}(23,18)=2.16$. Since $F_{0.05}(23,18)>2.00$, a common $\kappa$ can be assumed and the reversal test with several observations per polarity and a common precision can be performed (McFadden and McElhinny, 1990).

Thus, $N=N_{1}+N_{2}=41$, and the relevant angles are $\gamma_{0}=4.79^{\circ}$ and $\gamma_{c}=8.45^{\circ}$, where $\gamma_{0}$ is the observed angle between the two mean directions, and $\gamma_{c}$ is the critical angle between the two mean directions at which the null hypothesis of a common mean direction would be rejected with $95 \%$ confidence.

Since $\gamma_{0}<\gamma_{c}$ and $5^{\circ} \leq \gamma_{c} \leq 10^{\circ}$, the data pass the reversal test at the $95 \%$ confidence level, with a ' $\mathrm{B}$ ' classification.

\begin{tabular}{lllccc}
\hline \multicolumn{5}{c}{ TABLE 2B. KANGRA SECTION FOLD TEST } \\
\hline \hline Polarity & Limbs & $N$ & $\mu^{*}$ & $\xi_{2}{ }^{\dagger}$ & Critical value of $\xi \S$ \\
\hline Normal & In situ & 23 & $000.5^{\circ}, 48.6^{\circ}$ & 4.939 & 5.583 \\
Normal & Unfolded & 23 & $015.6^{\circ}, 29.6^{\circ}$ & 3.909 & 5.583 \\
Reverse & In situ & 18 & $190.1^{\circ},-47.9^{\circ}$ & 5.608 & 4.940 \\
Reverse & Unfolded & 18 & $201.0^{\circ},-30.3^{\circ}$ & 1.751 & 4.940 \\
\hline
\end{tabular}

Notes: The number of limbs (sensu McFadden, 1990) is given by $N$, and $\mu$ is the unit mean vector for the relevant normal or reverse set of limbs.

For the normal polarity limbs, the calculated values of $\xi_{2}$ for both in situ and unfolded data are less than the critical value at the $95 \%$ confidence limit. Thus, the timing of acquisition of magnetization is indeterminate from the normal polarity data. For the reverse polarity limbs, the in situ $\xi_{2}$ exceeds the critical value at the $95 \%$ confidence limit, whereas the unfolded $\xi_{2}$ is less than the critical value. Hence, the reverse polarity data suggest that the magnetization was acquired before the folding occurred (McFadden, 1990).

*The values given for $\mu$ are the declination and inclination, respectively.

tThe test statistic $\xi_{2}$ was used, since all limbs are on the same dip panel, and hence have dip directions within the same quadrant (see McFadden, 1990).

$\S$ The critical value of $\xi$ at the $95 \%$ confidence limit is calculated as $1.645 \sqrt{ }(N / 2)$. For more details, see McFadden (1990) 
currence with similar fauna in Pakistan rather than being 1-2 m.y. younger (Barry et al., 1982; Opdyke et al., 1979).

Magnetozone N6 is a single site reversal with normal polarity (Fig. 8). As at Kangra, this has been correlated with a cryptochron immediately above the top of chron 4An (8.699 Ma) described in the MPTS of Cande and Kent (1992). Magnetozone N4 of the Haritalyangar magnetic polarity stratigraphy is a short normal polarity magnetozone at about 9.2 Ma (2 class I sites at 970-980 m). We interpret this as the same very short normal polarity event as described at Kangra (magnetozone N5) and at several other sections in the Himalayan foreland (Tauxe, 1979; Tauxe and Opdyke, 1982).

\section{DISCUSSION AND SYNTHESIS}

Synthesis of data from the Himachal Pradesh reentrant and the remainder of the Siwalik foreland allows us to address several key problems concerning the evolution of both the Himalayan foreland and terrestrial foreland basins in general. In particular, the importance of hinterland tectonism and climate change in initiating and controlling gravel progradation into forelands is poorly understood (Heller and Paola, 1989, 1992; Paola et al., 1992; Burbank et al., 1988; DeCelles et al., 1987; DeCelles, 1994). Moreover, the role of three-dimensional variations in local to regional scale subsidence in localizing depositional systems has been little studied (Visser and Johnson, 1978; Burbank et al., 1988; Stern et al., 1992; Whiting and Thomas, 1994). The sedimentary rocks that most clearly record the interplay between tectonism, subsidence, and sediment supply are commonly deposited in the proximal foreland adjacent to the deforming hinterland. With continued shortening, such proximal deposits are usually overthrust or eroded. When such rocks are preserved and exposed within reentrants, such as in Himachal Pradesh, they can permit valuable insights into facets of basin evolution that are typically obscured in more distal settings.

\section{Evolution of Depositional Systems}

Prior to ca. $11.5 \mathrm{Ma}$, the sedimentary rocks in Himachal Pradesh were dominated by thick sequences of overbank deposits with occasional channel sandstones having southeasterly paleocurrent directions (Fig. 5). This facies is similar to the Lower Siwalik Chinji lithofacies in Pakistan and is thought to represent deposits of either the paleo-Indus river or a similar axial fluvial system (N. M. Johnson et al., 1982; Willis, 1993b; Burbank et al., 1996). The overlying Nahan lithofacies represents an abrupt coarsening upward (Fig. 5) and a change to fluvial systems with a

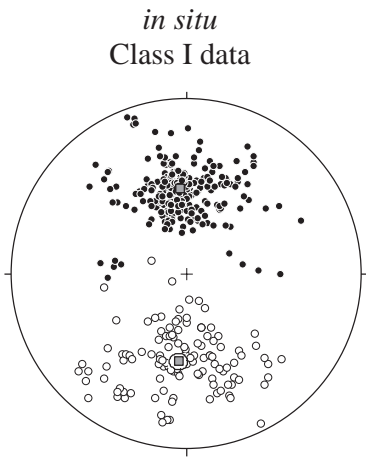

in situ Class I data bedding-corrected Class I data

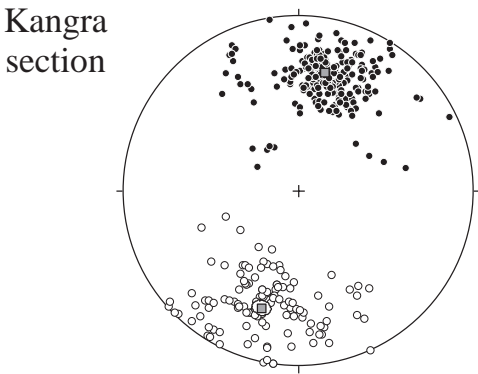

bedding-corrected Class I data

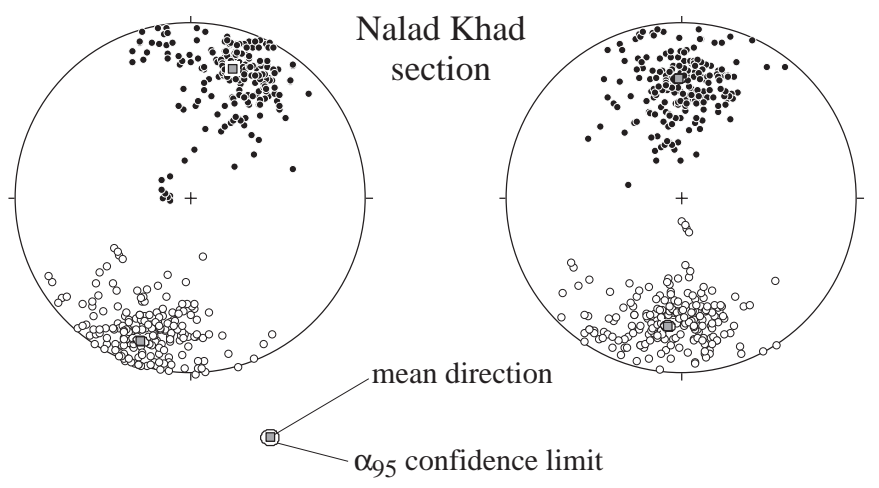

Figure 10. Equal-area projections of in situ and bedding-corrected class I data for the Kangra and Nalad Khad sections. Closed circles are samples that show a positive inclination; open circles are samples that show a negative inclination. Mean directions of normal and reverse populations are indicated by shaded boxes encircled by their respective $\alpha_{95}$ confidence intervals. The data pass the reversal test and fail the fold test at a $95 \%$ confidence interval. Mean declinations and inclinations for the total class I bedding-corrected data for each section (calculated using the normal samples and projecting the reverse samples through the origin) are $014.3^{\circ}, 31.3^{\circ}$ for

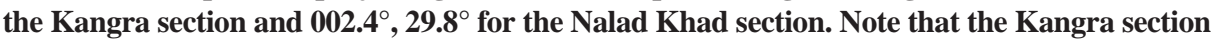
shows an apparent clockwise vertical axis rotation and that the Nalad Khad section shows no apparent rotation.

much increased discharge compared to the Chinji Formation (Willis, 1993a). This transition is roughly coeval across the entire northwest Himalayan foreland, and the Nahan and Nagri lithofacies are thought to represent the sediments of southeast-flowing axial rivers, probably the paleoIndus (Burbank, 1996; N. M. Johnson et al., 1982; Johnson et al., 1983; Willis, 1993a). Within the reentrant, sedimentary rocks deposited since 11 Ma document the encroachment on the axial river system of a large southwestward-flowing transverse river system (Figs. 5, 11, and 12). Paleocurrent directions suggest that the paleoIndus was progressively deflected westward by the prograding gravel front, which was confined to a narrow belt $\sim 40 \mathrm{~km}$ wide (Figs. 5, 11, and 12). Southwest of the prograding gravel front, small rivers developed with catchments entirely within the foreland (Fig. 12). In the interval from
10 to $7 \mathrm{Ma}$, major lithofacies boundaries vary in age by as much as 2-3 m.y. across distances of only $20-30 \mathrm{~km}$ (Figs. 11 and 12). Progradation rates for the conglomerate facies are similar to those reported for Pliocene conglomerates in the Jhelum reentrant ( $3 \mathrm{~cm} / \mathrm{yr}$; Raynolds and Johnson, 1985). By ca. 7.2 Ma, any facies variability was obliterated by widespread deposition of the typical Upper Siwalik "Boulder Conglomerate" lithofacies throughout the reentrant. The age of this widespread blanket of conglomerate (>7 Ma) is much older than either the late Pliocene gravels in the Jhelum reentrant or the formerly assumed Pleistocene age for "Boulder Conglomerate" in the foreland (Raynolds and Johnson, 1985; Burbank et al., 1988; Johnson et al., 1988). The age discrepancy may be partly due to the preservation of more proximal sedimentary rocks within the reentrant than elsewhere. In any case, in the con- 

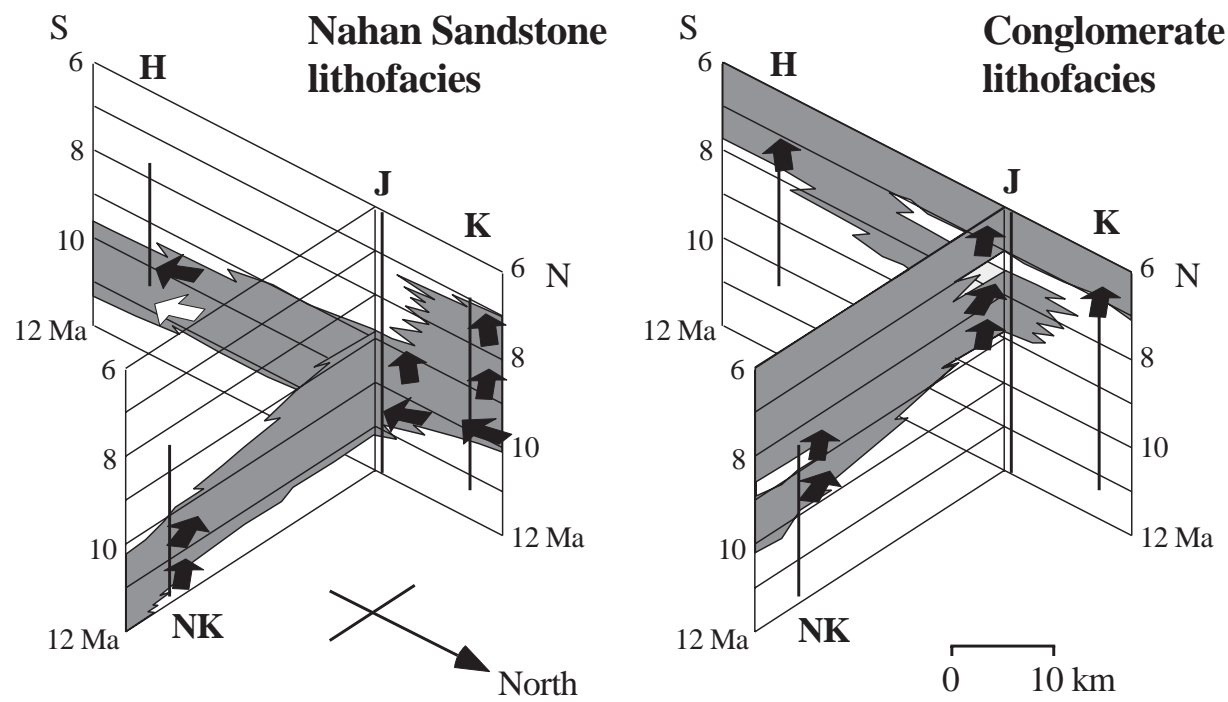

Figure 11. Temporal and spatial variability of the Nahan Sandstone and conglomerate lithofacies within the Himachal Pradesh reentrant. The figure shows two fence diagrams where the vertical axis is age (Ma). The magnetic sections measured are shown by the following abbreviations (and see Fig. 2): H-Haritalyangar, J-Jawalamukhi, K-Kangra, NK-Nalad Khad. The thick black vertical lines beneath each section name show the temporal range of the measured sections (e.g., the Kangra section spans 11.3 Ma to 6.9 Ma). The spatial and temporal distribution of the Nahan Sandstone and conglomerate lithofacies is shown by the gray pattern. Arrows show the paleoflow directions for the time line on which they are positioned, and for the section to which they are adjacent. Paleoflow direction arrows use the same data and symbols as in Figure 5. Note the orientation of the north arrow: Its top is toward the southwest. Note the progradation of the Middle Siwalik conglomerate shown on the fence portion between Nalad Khad and Jawalamukhi, and also the abrupt boundary of the Middle Siwalik conglomerate between Jawalamukhi and Kangra.

text of the entire foreland, conglomerate influx is highly diachronous, varying by nearly 7 m.y. between Nalad Khad and the Jhelum reentrant.

\section{Gravel Progradation and Sediment Accumulation}

The conglomerates that have been dated in Himachal Pradesh (10 Ma at Nalad Khad and 8.7 Ma at Jawalamukhi) are several million years older than the oldest dated extensive conglomerates found outside of the bounds of the reentrant (4-5 Ma; Burbank and Raynolds, 1988). These conglomerates all contain significant proportions of pink quartzite (Fig. 5). An identical quartzite, the Deoban Quartzite, is exposed today in the hanging wall of the Main Boundary thrust (e.g., near Bilaspur), but not elsewhere within the hinterland (Fig. 2). The abrupt appearance of these clasts in the foreland strata suggests that the Deoban source area was first exposed in the hanging wall of the Main Boundary thrust prior to ca. $11 \mathrm{Ma}$. Three hypotheses may be suggested to account for the Miocene appearance and progradation of such extensive hinterland-sourced conglomerates. (1) Climate change increased the discharge and sediment flux of transverse rivers, causing gravel progradation. (2) Gradual hinterland erosion without major tectonism led to a decrease in subsidence rates within the foreland and allowed the gravels to prograde post-tectonically. (3) Initiation of the Main Boundary thrust led to significant erosional relief developing above it, and gravels prograded into the foreland syntectonically. In order to evaluate these hypotheses, it is necessary to look at any changes in subsidence rates during this time interval within the reentrant and across the foreland.

At long time scales, sediment-accumulation rates (Fig. 13) may be taken as a proxy for subsidence rates in large, externally drained alluvial foreland basins where sediment supply rates are high (Burbank and Beck, 1989). Compacted rather than decompacted accumulation rates are used because differential compaction rates are poorly documented in terrestrial basins. Moreover, undeformed clastic dikes, undissolved clast contacts in conglomerates, and evidence for early cementation (Tauxe and Badgley, 1988) suggest little or no compaction. Beginning at around 11.5 to $11 \mathrm{Ma}$, an accumulation rate increase is seen in sections across the entire Himalayan foreland from Pakistan to Nepal (Meigs et al., 1995; Burbank, 1996). An increase of 35\%-75\% in accu- mulation rate is common for sections within the Pakistani foreland, although sections within the Himachal Pradesh reentrant show much smaller increases of $10 \%-25 \%$ from $0.4-0.5 \mathrm{~km} / \mathrm{m}$.y. to $0.5-0.6 \mathrm{~km} / \mathrm{m} . \mathrm{y}$. (Fig. 13). This may be a reflection of the contrast in flexural rigidities between the Indian and Pakistani foreland, with the rigidity estimated in Pakistan $\left(\sim 0.4 \times 10^{24} \mathrm{Nm}\right.$; Duroy et al., 1989) about an order of magnitude lower than that in India $\left(\sim 0.7 \times 10^{25} \mathrm{Nm}\right.$; Molnar, 1988). The increase in accumulation rates observed corresponds to an increase in subsidence rate and may be produced either by increasing the thrust load by $\sim 50 \%$, without a change in load locus, or by shifting loading to a more basinward position (Turcotte and Schubert, 1982). This latter alternative can be achieved by initiating a major new system of basement-involved thrusts. Meigs et al. (1995) suggested that this acceleration in subsidence was caused by middle-late Miocene initiation of the Main Boundary thrust (hypothesis 3). The transition from Chinji to Nagri lithofacies in Pakistan and from the Kasauli Formation (equivalent to the Chinji Formation) to the Nahan Sandstone in northwest India also occurred between 11.5 and 10.4 Ma (Burbank, 1996; N. M. Johnson et al., 1982; Johnson et al., 1983), and implies an increased paleodischarge (Willis, 1993a) of the axial river system (Figs. 4A, 5, 7A, and 11). In the Potwar Plateau region, this lithofacies and discharge change is accompanied by a threefold increase in the abundance of blue-green hornblende derived from the Kohistan terrane in northern Pakistan (Tahirkheli, 1979; Cerveny et al., 1989; Mulder, 1991). Apatite fission-track ages from the hanging wall of the Main Boundary thrust in northwest Pakistan are interpreted to suggest bedrock thrusting, uplift, and erosion commencing ca. $11 \mathrm{Ma}$ (Meigs et al., 1995) and constitute further independent evidence for the initiation of the Main Boundary thrust at this time over a large portion of the western Himalaya.

Key controls on the limits of gravel progradation also come from drill holes that penetrate through the Siwalik section within the Himachal Pradesh reentrant. Beginning with holes that are located along the trend of the gravel front, but $\sim 35 \mathrm{~km}$ more basinward of the Jawalamukhi thrust and in all more distal holes, there is no significant gravel in the Miocene and Pliocene Siwalik strata (Raiverman et al., 1983). If the gravel progradation rates that we have documented in the proximal foreland had been sustained for several million more years, we would expect the appearance of gravels in these more distal drill holes by Pliocene time. Their absence suggests that the gravel front either stalled or retrograded as the balance between loading, sediment supply, and gravel fraction changed through time. One 
potential mechanism to achieve this is by shifting the locus of deformation and the production of both topographic relief and gravel production to a more distal position. Such a possibility is supported by recent studies farther east in Nepal, which indicate a major reactivation of the Main Central thrust in late Miocene-early Pliocene time (Macfarlane, 1993; Harrison et al., 1998).

Several studies have discussed the effects of thrust belt reentrants on patterns of sedimentation
(Visser and Johnson, 1978; Burbank et al., 1988; Whiting and Thomas, 1994; Lawton et al., 1994). Theoretically, an irregular load on an elastic plate will produce a complex three-dimensional subsidence pattern, in which local differences in subsi-
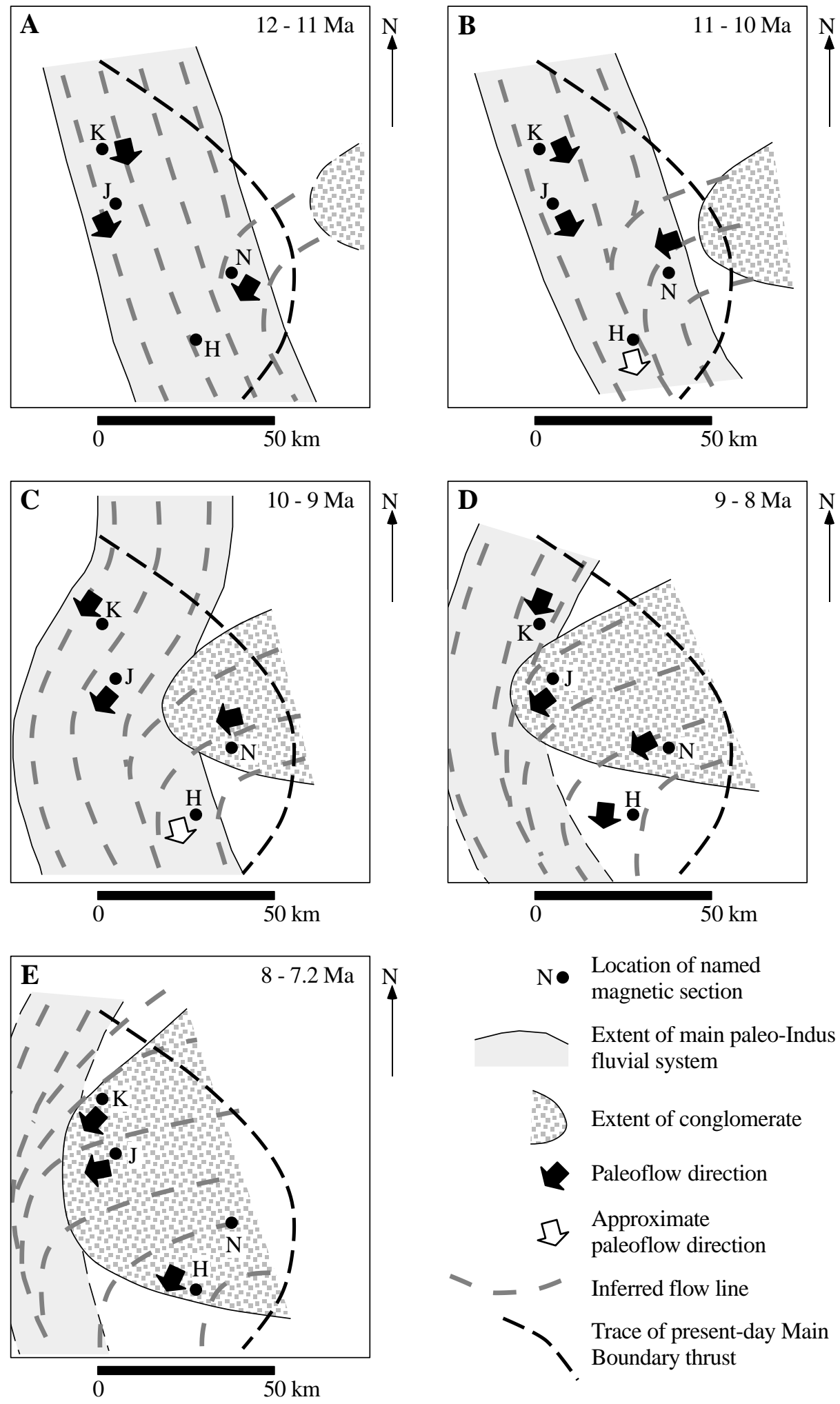

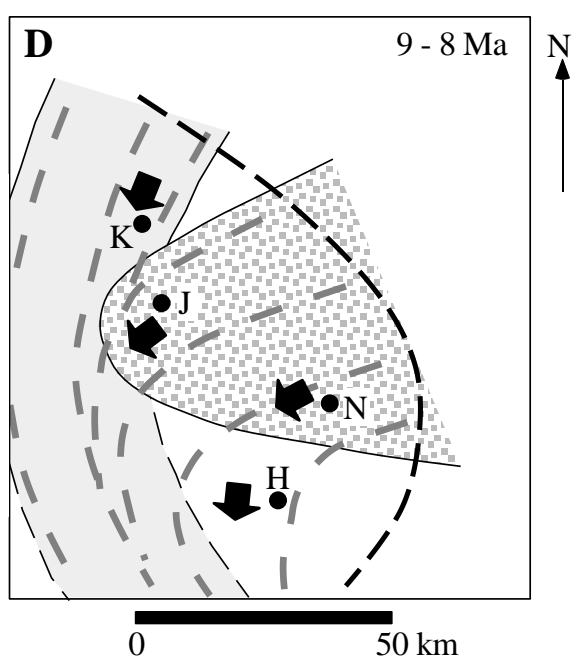

N• Location of named magnetic section

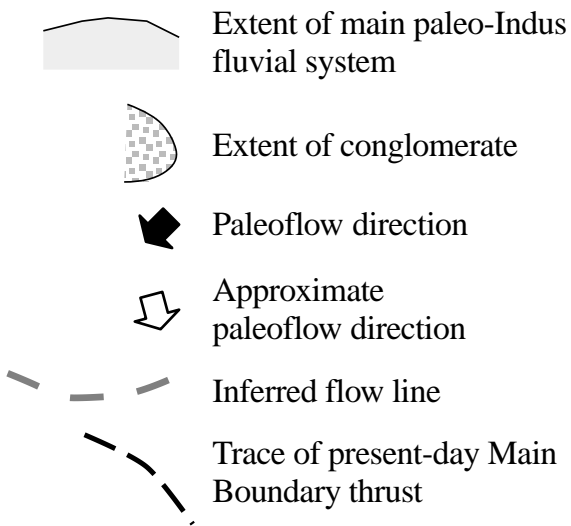

Figure 12. Depositional synthesis for the late Miocene Himachal Pradesh reentrant. The figure shows the position of the major transverse and axial fluvial systems and their flow directions for the following five time periods: (A) 12-11 Ma, (B) 11-10 $\mathrm{Ma},(\mathrm{C})$ 10-9 Ma, (D) 9-8 Ma, and (E) 8-7 Ma. KKangra, J-Jawalamukhi, H-Haritalyangar, N-Nalad Khad. Mean paleocurrent directions are shown by arrows; data and symbols are the same as in Figure 5. Large uncertainties in the position of the depositional systems are shown with dashed lines. The modern-day position of the Main Boundary thrust is shown as a geographical marker only; its position in late Miocene time was probably tens of kilometers farther east. 
dence are determined by the planform wavelength and amplitude of the load in comparison to the flexural rigidity of the lower plate (Timoshenko, 1940; Stern et al., 1992; Wessel, 1996). For an arcuate thrust load on a homogenous lower plate, an axis of relatively increased subsidence may coincide with the axis of the reentrant. The magnitude of lateral subsidence variation will decrease as the wavelength of the reentrant diminishes with respect to flexural rigidity. There is a striking association between Miocene facies distributions and the axis of the modern Himachal Pradesh reentrant, with the extensive upper-late Miocene conglomerates clearly confined to a zone about $40 \mathrm{~km}$ wide at Jawalamukhi (Figs. 2 and 12). Although increased axial subsidence within the bounds of reentrants has been reported elsewhere (Whiting and Thomas, 1994; Raynolds and Johnson, 1985; Burbank et al., 1988), all four sections in Himachal Pradesh show very similar accumulation rates (Fig. 13), providing no evidence for enhanced axial subsidence. Thus, the reason for the axial conglomeratic distribution remains obscure.

If the evidence for Main Boundary thrust initiation ca. $11.5 \mathrm{Ma}$ is accepted, then gravel progradation in Himachal Pradesh was syntectonic. Although no exact progradation rate can be measured in the Himachal Pradesh reentrant because the Jawalamukhi section is not directly downstream from the Nalad Khad section, pro- jection of lithofacies data on to a transect parallel to the paleocurrent directions suggests a progradation rate of $2-3 \mathrm{~cm} / \mathrm{yr}$ (Fig. 11). The total displacement along the Main Boundary thrust is unconstrained, but is likely to have been tens of kilometers (Srivastava and Mitra, 1994; Harrison et al., 1998). Thus, within 1-2 m.y. from the time of initiation of the Main Boundary thrust, an extensive gravel front had prograded tens of kilometers away from the active thrust front.

Gravel progradation has also been documented in Pliocene sedimentary rocks within the Jhelum reentrant, where a progradation rate of $3 \mathrm{~cm} / \mathrm{yr}$ has been determined (Raynolds, 1980; Raynolds and Johnson, 1985; Burbank et al., 1988). Although there are similarities between the rates and geometry of gravel progradation in the Jhelum reentrant and the Himachal Pradesh reentrant, there are also major differences. The Jhelum sites are $>60 \mathrm{~km}$ from the Main Boundary thrust and may have been in the medial part of the foreland when the conglomerate was deposited. Gravel progradation in the Jhelum reentrant is documented between 3 and 1 Ma (Burbank et al., 1988); if the Main Boundary thrust began motion at 11.5-11 Ma, then the Jhelum reentrant conglomerate postdates the initiation of thrusting by 8 m.y. Moreover, gravel progradation in the Jhelum reentrant is suggested to have occurred during a time of decreasing subsidence

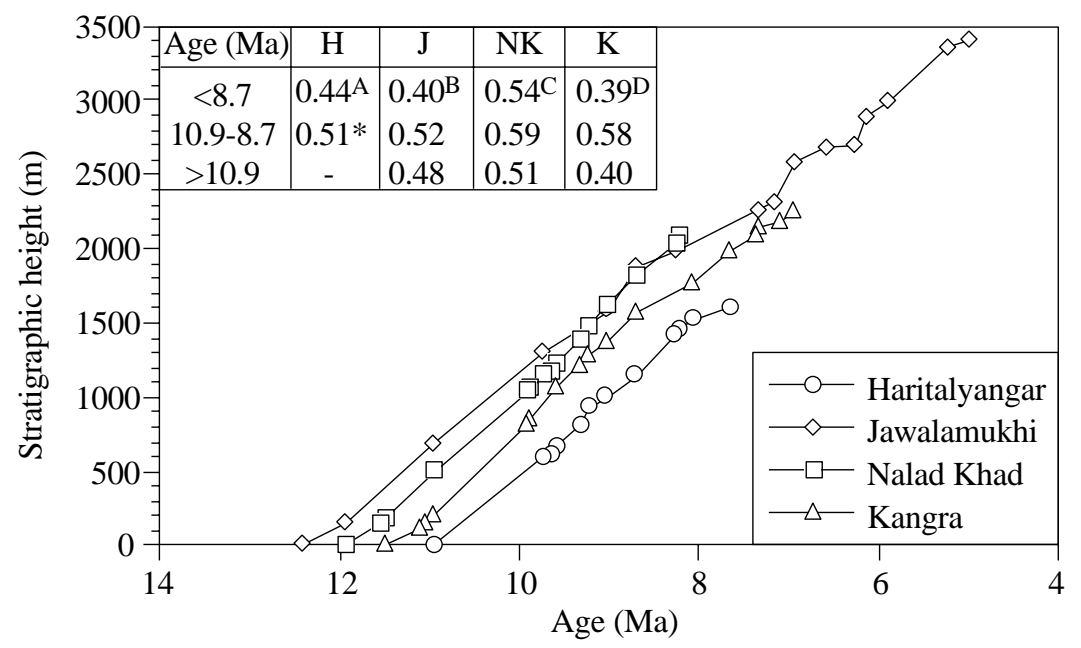

Figure 13. Sediment-accumulation curves for the Himachal Pradesh magnetic sections. The inset shows sediment-accumulation rates (in $\mathrm{km} / \mathrm{m}$.y.; equivalent to $\mathrm{mm} / \mathrm{yr}$ ) between chron boundaries identified in all four sections. The global magnetic polarity time scale of Cande and Kent (1995) was used for the correlation and calculation of sediment-accumulation rates. $\mathrm{H}-$ Haritalyangar, J-Jawalamukhi, NK-Nalad Khad, K-Kangra. The asterisk in the inset denotes minimum values of accumulation rate due to nonexposure of chron boundaries. The following upper (younger) boundaries were used to calculate rates younger than 8.7 Ma (and generally correspond to the stratigraphically highest chron boundary within any section): (A) 7.65 Ma, (B) 6.935 Ma, (C) 8.225 Ma, and (D) 6.935 Ma. An alternative correlation, less preferred by us, is also possible in the upper portion of the Jawalamukhi section (Meigs et al., 1995), which gives a sediment accumulation rate of $0.63 \mathrm{~km} / \mathrm{Ma}$ from $8.7-6.935 \mathrm{Ma}$.

(Burbank et al., 1988; Heller and Paola, 1992). In foreland basins, gravel progradation is commonly controlled by the ratio of subsidence to sediment supply and by the fraction of gravel in the sediment. For a fixed sediment supply and gravel fraction, the increase in accommodation space caused by thrust-induced subsidence will confine syntectonic conglomerates close to the mountain front (Heller et al., 1988; Paola et al., 1992; DeCelles et al., 1987; DeCelles, 1994). Long-lived syntectonic gravel progradation, in spite of accelerated subsidence, may occur if there is a sufficient increase in either the sediment flux or the fraction of gravel carried by rivers entering the foreland (Paola et al., 1992). For any given load, the flexural rigidity of the underlying plate determines the spatial distribution of subsidence, such that a broader, shallower deflection will characterize a more rigid plate. Thus a homogeneous thrust load that generates a constant sediment supply and gravel fraction along its length will produce spatially variable gravel progradation or retrogradation that reflects differences in the flexural rigidity. We predict that during thrust loading, the increase in sediment supply or gravel fraction necessary to increase the rate of gravel progradation in the proximal part of the basin would be larger for the less rigid Jhelum reentrant than for Himachal Pradesh. Thus, along-strike variations in flexural rigidity, in addition to changes in climate, source-area size, erodibility, and rock strength, will combine to modulate gravel progradation into foreland basins.

\section{SUMMARY}

Structural reentrants can provide windows into proximal parts of foreland basins that are commonly not exposed. In the northwest Indian foreland, much of the medial part of the Miocene foreland has been overthrust. However, within the Himachal Pradesh reentrant, both the medial foreland and parts of the proximal foreland are exposed, giving key insights to the history of the Himalaya (Fig. 2).

The boundaries between major Siwalik lithofacies in Pakistan are commonly not time transgressive. Although similar lithofacies are present in Himachal Pradesh, their boundaries display extensive temporal and spatial variability (Figs. 5, 11, and 12). Magnetostratigraphic time control has played a critical role in understanding this variability and its relationship to hinterland evolution: In the absence of such control, the extensive Middle Siwalik conglomerates at Jawalamukhi and Nalad Khad were previously assigned to the Upper Siwalik "Boulder Conglomerate" of Quaternary age.

The 10 Ma conglomerates at Nalad Khad are the oldest extensive conglomerates that have 
been dated in the Siwalik foreland. They contain a significant proportion of clasts of rock types found today only in the hanging wall of the Main Boundary thrust (Deoban Quartzite). Together with sediment-accumulation curves and previously published sandstone heavy mineral compositions and hinterland fission-track dating, these data suggest a change in the position of the hinterland load due to creation of a major new thrust system ca. 11.5 Ma: the Main Boundary thrust (Meigs et al., 1995; Burbank et al., 1996). The Middle Siwalik conglomerates at Nalad Khad and Jawalamukhi are notable not only for their age, but also for their thickness (hundreds of meters) and their confinement to a facies belt with relatively abrupt lateral boundaries.

The close association of the axis of the modern-day reentrant and the confined belt of middle-late Miocene conglomerates suggests that there may have been some focusing of the transverse fluvial system by the reentrant in Miocene time (Fig. 12). In contrast to the Jhelum reentrant (Raynolds and Johnson, 1985; Burbank et al., 1988), sediment-accumulation curves in the Himachal Pradesh reentrant show no increased subsidence along the axis of the prograding gravel front (Fig. 13). The influence of the geometry and topography of reentrants in producing subtle changes in subsidence that apparently focus facies at large distances is still poorly constrained and understood, although such focusing is suggested by the conglomerate outcrop patterns in Himachal Pradesh. We suggest that the flux of sediment into the Himalayan foreland is always sufficiently high to fill available sediment accommodation space. Under such conditions, gravel progradation may arise from an increase in the fraction of gravel, an increase in the total sediment flux with no change in grain-size distribution, or reduced rates of subsidence. In Himachal Pradesh, progradation is coeval with a subsidence-rate increase, rather than a decrease, so that the last mechanism for progradation can be discounted. A localized increase in the fraction of gravel entering the foreland is interpreted to have resulted from a basinward jump of the deformation front that occurred as the Main Boundary thrust was initiated. The uplifted resistant rocks of the Main Boundary thrust hanging wall became the source of an increased gravel fraction that sustained long-lived progradation across the proximal foreland.

\section{ACKNOWLEDGMENTS}

This work was supported by National Science Foundation grant EAR-9205501 and National Atmospheric and Space Agency grant NAGW3762 to Burbank, and by a Shell International Petroleum Company Postgraduate Bursary and a
University of Southern California Keck Foundation Fellowship to Brozović. We acknowledge the help of Jagadish Pandey and his colleagues at the Geoscience Research Group, KDMIPE, Oil and Natural Gas Corporation, Dehra Dun. Brozović thanks Hameeduddin Mahmood and family, Joginder Singh, Ravindra Sharma, Ashok Nehra, and Aman Mahajan. We also thank Andrew Meigs for his critical comments. This manuscript benefited significantly from the thoughtful reviews of C. Paola, R. Butler, and P. Heller.

\section{REFERENCES CITED}

Allen, P. A., and Allen, J. R., 1990, Basin analysis; Principles and applications: Oxford, Blackwell Scientific Publications, $451 \mathrm{p}$.

Appel, E., Rösler, W., and Corvinus, G., 1991, Magnetostratigraphy of the Miocene-Pleistocene Surai Khola Siwaliks in West Nepal: Geophysical Journal International, v. 105, p. 191-198.

Barry, J. C., Lindsay, E. H., and Jacobs, L. L., 1982, A biostratigraphic zonation of the Middle and Upper Siwaliks of the Potwar Plateau of northern Pakistan: Palaeogeography, Palaeoclimatology, Palaeoecology, v. 37, p. 95-130.

Beck, R. A., Burbank, D. W., Sercombe, W. J., Riley, G. W., Barndt, J. K., Berry, J. R., Afzal, J., Khan, A. M., Jurgen, H., Metje, J., Cheema, A., Shafique, N. A., Lawrence, R. D., and Khan, M. A., 1995, Stratigraphic evidence for an early collision between northwest India and Asia: Nature, v. 373 , p. $55-58$.

Bossart, P., and Ottiger, R., 1989, Rocks of the Murree Formation in northern Pakistan: Indicators of a descending foreland basin of late Paleocene to middle Eocene age: Eclogae Geologicae Helvetiae, v. 82, p. 133-165.

Burbank, D. W., 1992, Causes of recent Himalayan uplift deduced from deposited patterns in the Ganges basin: Nature, v. 357, p. 680-682

Burbank, D. W., 1996, The Himalayan Foreland Basin, in Yin, A., and Harrison, T. M., eds., The tectonic evolution of Asia: Cambridge, Cambridge University Press, 678 p.

Burbank, D. W., and Beck, R. A., 1989, Early Pliocene uplift of the Salt Range: Temporal constraints on thrust wedge development, northwest Himalaya, Pakistan, in Malinconico, L. L., Jr., and Lillie, R. J., eds., Tectonics of the Western Himalaya: Geological Society of America Special Paper 232, p. 113-128.

Burbank, D. W., and Beck, R. A., 1991, Models of aggradation versus progradation in the Himalayan foreland: Geologische Rundschau, v. 80 , 3, p. 623-638.

Burbank, D. W., and Johnson, G. D., 1983, The late Cenozoic chronologic and stratigraphic development of the Kashmir intermontane basin, northwestern Himalaya: Palaeogeography, Palaeoclimatology, Palaeoecology, v. 43, p. 205-235.

Burbank, D. W., and Raynolds, R. G. H., 1988, Stratigraphic keys to the timing of thrusting in terrestrial foreland basins: Applications to the northwest Himalaya, in Kleinspehn, K. L., and Paola, C., eds., New perspectives in basin analysis: New York, Springer-Verlag, p. 331-351.

Burbank, D. W., Raynolds, R. G. H., and Johnson, G. D., 1986, Late Cenozoic tectonics and sedimentation in the northwestern Himalayan foredeep: II. Eastern limb of the Northwest Syntaxis and regional synthesis, in Allen, P., and Homewood, P., eds., Foreland basins: International Association of Sedimentologists Special Publication 8 , p. 293-305.

Burbank, D. W., Beck, R. A., Raynolds, R. G. H., Hobbs, R., and Tahirkheli, R. A. K., 1988, thrusting and gravel progradation in foreland basins: A test of post-thrusting gravel dispersal: Geology, v. 16, p. 1143-1146.

Burbank, D. W., Derry, L. A., and France-Lanord, C., 1993, Reduced Himalayan sediment production $8 \mathrm{My}$ ago despite an intensified monsoon: Nature, v. 364, p. 48-50.

Burbank, D. W., Meigs, A. J., and Brozović, N., 1996, Interactions of growing folds and coeval depositional systems: Basin Research, v. 8, p. 199-223.
Cande, S. C., and Kent, D. V., 1992, A new geomagnetic polarity time scale for the Late Cretaceous and Cenozoic: Journal of Geophysical Research, v. 97, no. B10, p. 13,917-13,953.

Cande, S. C., and Kent, D. V., 1995, Revised calibration of the geomagnetic polarity timescale for the Late Cretaceous and Cenozoic: Journal of Geophysical Research, v. 100, no. B4, p. 6093-6095.

Cerveny, P. F., Johnson, N. M., Tahirkheli, R. A. K., and Bonis, N. R., 1989, Tectonic and geomorphic implications of Siwalik Group heavy minerals, Potwar Plateau, Pakistan, in Malinconico, L. L., Jr., and Lillie, R. J., eds., Tectonics of the Western Himalaya: Geological Society of America Special Paper 232, p. 129-136.

Critelli, S., and Garzanti, E., 1994, Provenance of the lower Tertiary Murree red beds (Hazara-Kashmir syntaxis, Pakistan) and initial rising of the Himalayas: Sedimentary Geology, v. 89, p. 265-284.

DeCelles, P. G., 1994, Late Cretaceous-Paleocene synorogenic sedimentation and kinematic history of the Sevier thrust belt, northeast Utah and southwest Wyoming: Geological Society of America Bulletin, v. 106, p. 32-56.

DeCelles, P. G., Tolson, R. B., Graham, S. A., Smith, G. A., Ingersoll, R. V., White, J., Schmidt, C. J., Rice, R., Moxon, I., Lemke, L., Handschy, J. W., Follo, M. F., Edwards, D. P., Cavazza, W., Caldwell, M., and Bargar, E., 1987, Laramide thrust-generated alluvial-fan sedimentation, Sphinx Conglomerate, southwestern Montana: American Association of Petroleum Geologists Bulletin, v. 71,2 , p. $135-155$

DeCelles, P. G., Pile, H. T., and Coogan, J. C., 1993, Kinematic history of the Meade thrust based on provenance of the Bechler Conglomerate at Red Mountain, Idaho, Sevier thrust belt: Tectonics, v. 12, p. 1436-1450.

Duroy, Y., Farah, A., and Lillie, R. J., 1989, Subsurface densities and lithospheric flexure of the Himalayan foreland in Pakistan, in Malinconico, L. L., Jr., and Lillie, R. J., eds., Tectonics of the western Himalayas: Geological Society of America Special Paper 232, p. 217-236.

Fisher, R. A., 1953, Dispersion on a sphere: Royal Society of London Proceedings, v. A217, p. 295-305.

Flemings, P. B., and Jordan, T. E., 1989, A synthetic stratigraphic model of foreland basin development: Journal of Geophysical Research, v. 94, no. B4, p. 3851-3866.

Flemings, P. B., and Jordan, T. E., 1990, Stratigraphic modeling of foreland basins: Interpreting thrust deformation and lithosphere rheology: Geology, v. 18, p. 430-434

Fraser, G. S., and DeCelles, P. G., 1992, Geomorphic controls on sediment accumulation at margins of foreland basins: Basin Research, v. 4, p. 233-252.

Gansser, A., 1964, Geology of the Himalayas: London, Interscience, $289 \mathrm{p}$.

Graham, S. A., Tolson, R. B., DeCelles, P. G., Ingersoll, R. V. Bargar, E., Caldwell, M., Cavazza, W., Edwards, D. P., Follo, M. F., Handschy, J. F., Lemke, L., Moxon, I., Rice, R., Smith, G. A., and White, J., 1986, Provenance modeling as a technique for analysing source terrane evolution and controls on foreland sedimentation, in Allen, P., and Homewood, P., eds., Foreland basins: International Association of Sedimentologists Special Publication 8 , p. 425-436.

Harrison, T. M., Grove, M., Lovera, O. M., and Catlos, E. J., 1998, A model for the origin of Himalayan anatexis and inverted metamorphism: Journal of Geophysical Research, v. 103, p. 27017-27032.

Heller, P. L., and Paola, C., 1989, The paradox of Lower Cretaceous gravels and the initiation of thrusting in the Sevier orogenic belt, United States Western Interior: Geological Society of America Bulletin, v. 101, p. 864-875.

Heller, P. L., and Paola, C., 1992, The large-scale dynamics of grain-size variation in alluvial basins, 2: Application to syntectonic conglomerate: Basin Research, v. 4, p. 91-102.

Heller, P. L., Angevine, C. L., Winslow, N. S., and Paola, C., 1988, Two-phase stratigraphic model of foreland basin development: Geology, v. 16, p. 501-504.

Johnson, G. D., and Vondra, C. F., 1972, Siwalik sediments in a portion of the Punjab reentrant: The sequence at Haritalyangar, District Bilaspur, H.P.: Himalayan Geology, v. 2 , p. $118-144$.

Johnson, G. D., Johnson, N. M., Opdyke, N. D., and Tahirkheli, R. A. K., 1979, Magnetic reversal stratigraphy and sedimentary tectonic history of the Upper Siwalik Group, eastern Salt Range and southwestern Kashmir, in 
Farrah, A., and DeJong, K. A., eds., Geodynamics of Pakistan: Quetta, Geological Survey of Pakistan, p. 149-165.

Johnson, G. D., Zeitler, P. K., Naeser, C. W., Johnson, N. M., Summers, D. M., Frost, C. D., Opdyke, N. D., and Tahirkheli, R. A. K., 1982, The occurrence and fissiontrack ages of late Neogene and Quaternary volcanic sediments, Siwalik Group, northern Pakistan: Palaeogeography, Palaeoclimatology, Palaeoecology, v. 37, p. 63-93.

Johnson, G. D., Opdyke, N. D., Tandon, S. K., and Nanda, A. C., 1983, The magnetic polarity stratigraphy of the Siwalik Group at Haritalyangar (India) and a new last appearance datum for Ramapithecus and Sivapithecus in Asia: Palaeogeography, Palaeoclimatology, Palaeoecology, v. 44, p. 223-249.

Johnson, N. M., and McGee, V. E., 1983, Magnetic polarity stratigraphy: Stochastic properties of data, sampling problems and the evaluation of interpretations: Journal of Geophysical Research, v. 88, p. 1213-1221.

Johnson, N. M., Opdyke, N. D., Johnson, G. D., Lindsay, E. H., and Tahirkheli, R. A. K., 1982, Magnetic polarity stratigraphy and ages of Siwalik Group rocks of the Potwar Plateau, Pakistan: Palaeogeography, Palaeoclimatology, Palaeoecology, v. 37, p. 17-42.

Johnson, N. M., Stix, J., Tauxe, L., Cerveny, P. F., and Tahirkheli, R. A. K., 1985, Paleomagnetic chronology, fluvial processes, and tectonic implications of the Siwalik deposits near Chinji Village, Pakistan: Journal of Geology, v. 93, p. 27-40.

Johnson, N. M., Sheikh, K. A., Dawson-Saunders, E., and McRae, L. E., 1988, The use of magnetic-reversal time lines in stratigraphic analysis: A case study in measuring variability in sedimentation rates, in Kleinspehn, K. L., and Paola, C., eds., New perspectives in basin analysis: New York, Springer-Verlag, p. 189-200.

Karunakaran, C., and Rao, A. R., 1979, Status of exploration for hydrocarbon in the Himalayan region-Contributions to stratigraphy and structure: Geological Survey of India Miscellaneous Publications, v. 41, p. 1-66.

Khan, M. J., Opdyke, N. D., and Tahirkheli, R. A. K., 1988 Magnetic stratigraphy of the Siwalik Group, Bhittani, Marwat, and Khasor ranges, northwestern Pakistan and the timing of Neogene tectonics of the Trans Indus: Journal of Geophysical Research, v. 93, p. 11,773-11,790.

Lawton, T. F., Boyer, S. E., and Schmitt, J. G., 1994, Influence of inherited taper on structural variability and conglomerate distribution, Cordilleran fold and thrust belt, western United States: Geology, v. 22, p. 339-342.

Leathers, M. R., 1987, Balanced structural cross section of the western salt range and Potwar Plateau, Pakistan [Master's thesis]: Oregon State University.

Lillie, R. J., Johnson, G. D., Yousaf, M., Zamin, A. S. H., and Yeats, R. S., 1987, Structural development within the Himalayan fold-and-thrust belt of Pakistan, in Beaumont, C., and Tankard, A. J., eds., Sedimentary basins and basin-forming mechanisms: Canadian Society of Petroleum Geologists Memoir 12, p. 379-392.

Macfarlane, A. M., 1993, chronology of tectonic events in the crystalline core of the Himalaya, Langtang National Park, central Nepal: Tectonics, v. 12, p. 1004-1025.

McFadden, P. L., 1990, A new fold test for palaeomagnetic studies: Geophysical Journal International, v. 103, p. 163-169.

McFadden, P. L., and McElhinny, M. W., 1990, classification of the reversal test in palaeomagnetism: Geophysical Journal International, v. 103, p. 725-729.

Meghraoui, M., Jaegy, R., Lammali, K., and Albarede, F., 1988, Late Holocene earthquake sequences on the El Asnam (Algeria) thrust fault: Earth and Planetary Science Letters v. 90 , p. $187-203$

Meigs, A. J., Burbank, D. W., and Beck, R. A., 1995, Middlelate Miocene ( $>10 \mathrm{Ma}$ ) formation of the Main Boundary thrust in the western Himalaya: Geology, v. 23, p. 423-426.

Molnar, P., 1988, A review of geophysical constraints on the deep structure of the Tibetan Plateau, the Himalaya and the Karakoram, and their tectonic implications: Royal So- ciety of London Philosophical Transactions, ser. A, v. 326, p. $33-88$

Mulder, T. J., 1991, Isochronous paleogeographies and stratigraphic evolution of the northwest Himalayan foredeep, 8.5-5 Ma, central and eastern Potwar Plateau, Pakistan [Master's thesis]: Los Angeles, University of Southern California, $107 \mathrm{p}$.

Mulder, T. J., and Burbank, D. W., 1993, The impact of incipient uplift on patterns of fluvial deposition: An example from the Salt Range, Northwest Himalayan Foreland, Pakistan, in Marzo, M., and Puigdefabregas, C., eds., Alluvial sedimentation: Oxford, Blackwell Scientific Publications, 17 , p. 521-539.

Najman, Y., Clift, P., Johnson, M. R. W., and Robertson, A. H. F., 1993, Early stages of foreland basin evolution in the Lesser Himalaya, N India, in Treloar, P. J., and Searle, M. P., eds., Himalayan tectonics: Geological Society [London] Special Publication 74, p. 541-558.

Opdyke, N. D., Lindsay, E. H., Johnson, G. D., Johnson, N. M., Tahirkheli, R. A. K., and Mizra, M. A., 1979, Magnetic polarity stratigraphy and vertebrate paleontology of the Upper Siwalik Subgroup of northern Pakistan: Palaeogeography, Palaeoclimatology, Palaeoecology, v. 27, p. 1-34.

Paola, C., Heller, P. L., and Angevine, C. L., 1992, The largescale dynamics of grain-size variation in alluvial basins, 1: Theory: Basin Research, v. 4, p. 73-90.

Pivnik, D. A., and Johnson, G. D., 1995, Depositional response to Pliocene-Pleistocene foreland partitioning in northwest Pakistan: Geological Society of America Bulletin, v. 107, p. 895-922.

Powers, P. M., and Lillie, R. J., 1995, Structure and shortening rates of the Himalayan foreland fold-and-thrust belt, northwest India: Geological Society of America Abstracts with Programs, v. 27, no. 6, p. 220

Quade, J., Cerling, T. E., and Bowman, J. R., 1989, Development of Asian monsoon revealed by marked ecological shift during latest Miocene in northern Pakistan: Nature, v. 342 , p. $163-166$.

Raiverman, V., Kunte, S. V., and Mukherjea, A., 1983, Basin geometry, Cenozoic sedimentation and hydrocarbon in north western Himalaya and Indo-Gangetic plains: Petroleum Asia Journal, v. 6, p. 67-92.

Raiverman, V., Ganju, J. L., Ram Jokhan, and Misra, V. N., 1990, Geological map of Himalayan foothills between Ravi and Yamuna rivers: Dehra Dun, India, Institute of Petroleum Exploration, scale: 1:100,000.

Raymo, M. E., and Ruddiman, W. F., 1992, Tectonic forcing of late Cenozoic climate change: Nature, v. 359, p. 117-122.

Raynolds, R. G. H., 1980, The Plio-Pleistocene structural and stratigraphic evolution of the eastern Potwar Plateau, Pakistan [Ph.D. dissert.]: Hanover, New Hampshire, Dartmouth College, $265 \mathrm{p}$.

Raynolds, R. G. H., and Johnson, G. D., 1985, Rates of Neogene depositional and deformational processes, northwest Himalayan foredeep margin, Pakistan, in Snelling, N. J., ed., The chronology of the geological record: Geological Society [London] Memoir 10, p. 291-311.

Ruddiman, W. F., and Kutzbach, J. E., 1989, Forcing of the late Cenozoic Northern Hemisphere climate by plateau uplift in southeast Asia and the American southwest: Journal of Geophysical Research, v. 94, p. 18409-18427.

Shah, S. M. I., 1977, Stratigraphy of Pakistan: Geological Survey of Pakistan Memoir 12, 138 p.

Sinclair, H. D., and Allen, P. A., 1992, Vertical versus horizontal motions in the Alpine orogenic wedge: Stratigraphic response in the foreland basin: Basin Research, v. 4, p. 215-232.

Sinclair, H. D., Coakley, B. J., Allen, P. A., and Watts, A. B., 1991, Simulation of foreland basin stratigraphy using a diffusion model of mountain belt uplift and erosion: An example from the Central Alps, Switzerland: Tectonics, v. 10, p. 599-620.

Srivastava, P., and Mitra, G., 1994, thrust geometries and deep structure of the outer and lesser Himalaya, Kumaon and Garwhal (India): Implications for evolution of the Himalayan fold-and-thrust belt: Tectonics, v. 13, p. 89-109.
Stern, T. A., Quinlan, G. M., and Holt, W. E., 1992, Basin formation behind an active subduction zone: Three-dimensional flexural modeling of Wanganui Basin, New Zealand: Basin Research, v. 4, p. 197-214.

Tahirkheli, R. A. K., 1979, Geology of Kohistan and adjoining Eurasian and Indo-Pakistan continents, Pakistan: University of Peshawar Geological Bulletin, Special Issue, v. 11 p. 1-30.

Talling, P. J., and Burbank, D. W., 1993, Assessment of uncertainties in magnetostratigraphic dating of sedimentary strata, in Asissaoiu, A., McNeil, D. F., and Hurley, N. F. eds., Applications of paleomagnetism to sedimentary geology: SEPM (Society for Sedimentary Geology) Special Publication 49, p. 59-69.

Talling, P. J., Lawton, T. F., Burbank, D. W., and Hobbs, R. S. 1995, Evolution of latest Cretaceous-Eocene nonmarine deposystems in the Axhandle piggyback basin of central Utah: Geological Society of America Bulletin, v. 107, p. 297-315.

Tandon, S. K., and Rangaraj, S., 1979, Sedimentary tectonics of the Siwalik sequence, southeast of the Ravi structura reentrant, in Saklani, P. S., ed., Structural geology of the Himalaya: New Delhi, Today and Tomorrow's Printers and Publishers, p. 273-283.

Tauxe, L., 1979, A new date for Ramapithecus: Nature, v. 282 p. $399-401$

Tauxe, L., and Badgley, C., 1988, Stratigraphy and remanence acquisition of a paleomagnetic reversal in alluvial Siwalik rocks of Pakistan: Sedimentology, v. 35, p. 697-715.

Tauxe, L., and Opdyke, N. D., 1982, A time framework based on magnetostratigraphy for the Siwalik sediments of the Khaur area, northern Pakistan: Palaeogeography, Palaeoclimatology, Palaeoecology, v. 37, p. 43-61.

Timoshenko, S., 1940, Theory of plates and shells: New York, McGraw-Hill, $492 \mathrm{p}$.

Turcotte, D. L., and Schubert, G., 1982, Geodynamics-Applications of continuum physics to geological problems: New York, John Wiley \& Sons, $450 \mathrm{p}$.

Visser, C. F., and Johnson, G. D., 1978, Tectonic control of late Pliocene molasse sedimentation in a portion of the Jhelum reentrant, Pakistan: Geologische Rundschau, v. 67 , p. $15-37$.

Waschbusch, P. J., and Royden, L. H., 1992, Spatial and temporal evolution of foredeep basins: Lateral strength variations and inelastic yielding in continental lithosphere: Basin Research, v. 4, p. 179-196.

Watts, A. B., 1992, The effective elastic thickness of the lithosphere and the evolution of foreland basins: Basin Research, v. 4, p. 169-178.

Wessel, P., 1996, Analytical solutions for 3-D flexural deformation of semi-infinite elastic plates: Geophysical Journal International, v. 124, p. 907-918

Whiting, B. M., and Thomas, W. A., 1994, Three-dimensional controls on subsidence of a foreland basin associated with a thrust-belt recess: Black Warrior basin, Alabama and Mississippi: Geology, v. 22, p. 727-730.

Willis, B., 1993a, Ancient river systems in the Himalayan foredeep, Chinji Village area, northern Pakistan: Sedimentary Geology, v. 88, p. 1-76.

Willis, B., 1993b, Evolution of Miocene fluvial systems in the Himalayan foredeep through a two kilometer-thick succession in northern Pakistan: Sedimentary Geology, v. 88, p. 77-121.

Yeats, R. S., and Lillie, R. J., 1991, Contemporary tectonics of the Himalayan frontal fault system: Folds, blind thrusts and the 1905 Kangra earthquake: Journal of Structural Geology, v. 13, p. 215-225.

Yeats, R. S., Nakata, T., Farah, A., Fort, M., Mirza, M. A., Pandey, M. R., and Stein, R. S., 1992, The Himalayan frontal fault system: Annales Tectonicae, v. 6, p. 85-98.

ManusCriPt Received by the Society May 22, 1997

Revised Manuscript Received July 12, 1999

MANUSCRIPT ACCEPTED SEPTEMBER 2, 1999 